This is a postprint version of the following published document:

Ramos Muñoz, D. (2015). Bankruptcy-remote transactions and bankruptcy law : a comparative approach (part 1) : changing the focus on vehicle shielding . En: Capital Markets Law Journal, 10 (2), pp. 239-274

DOI: $10.1093 / \mathrm{cmlj} / \mathrm{kmv} 020$

(C) The Author(s) (2015). Published by Oxford University Press. All rights reserved. 


\section{Bankruptcy-remote transactions and bankruptcy law_a comparative approach (part 1): changing the focus on vehicle shielding}

David Ramos Muñoz*

\section{Key points}

- Conventional wisdom about bankruptcy remote transactions tends to be grounded on two assumptions. First, bankruptcy remote transactions are a highly specific, and borderline case, of anecdotal relevance for bankruptcy policy. Second, bankruptcy remote transactions are either a welcome or dangerous innovation, with little scope for nuances.

- This article tries to examine the relationship of bankruptcy remote transactions and bankruptcy policy in a new light, using precedent and scholarly analysis from different jurisdictions.

- First, the article establishes the different ideas encompassed by the concept of 'bankruptcy remoteness', and puts bankruptcy remote structures in the broader context of bankruptcy policy.

- Second, the article uses the 'vehicle shielding' concept of bankruptcy remoteness and tests traditional legal threats such as avoidance, re characterization or substantive consolidation, seeing whether their academic importance from an academic perspective is matched by their relevance as a threat in practice.

- Third, the article analyses the instances where vehicle shielding has actually been, or can be, put in jeopardy, and the reasons for it.

- The article concludes that bankruptcy remote transactions should cease to be considered a marginal case for bankruptcy law. Rather, the tensions between different goals, at the core of bankruptcy policy, are very present in the context of these transactions, only such tensions materialize in ways different from that those originally envisaged. Academic analysis should adjust to this complex reality, rather than the opposite.

\section{Introduction}

Bankruptcy-remote transactions and their accompanying Special Purpose Vehicles (SPVs, also called Special Purpose Entities, or SPEs) have enjoyed widespread use in the past, and grown in complexity and sophistication. On another level, the debate on bankruptcy policy has allowed bankruptcy law to be seen in light of the need to maximize value and society's other goals. However, both types of analysis have so far been disconnected: practical studies of securitization and other bankruptcy-remote transactions (which are normally favourable to it without qualifications) do not normally take into consideration the broader implications of the use of SPVs/SPEs in policy terms.

\footnotetext{
* Universidad Carlos III de Madrid.
} 
For policy analysis, on the other hand, bankruptcy-remote transactions are more of an isolated example or anecdote, and, if they are given more relevance as a test case, they tend to be painted in broad brushstrokes, as either a welcome or dangerous innovation, without paying much attention to the details of each type of transaction.

This article tries to build a bridge between theory and practice, by studying bankruptcy-remote structures and their challenges in bankruptcy law, but also the way those challenges fit in the broader debate on bankruptcy policy. To reinforce this perspective the article takes a comparative approach, and, in addition to the USA, it uses the law of countries such as the UK, France, Spain or Italy as a point of comparison.

The article begins by stating the terms of the debate, the use of securitization and bankruptcy-remote structures, their legal meaning, and significance in terms of the bankruptcy debate (Section 2). It then explores the legal devices that have traditionally been considered as the more important threats for securitization, since they imperil both the asset transfer and the separateness of the vehicle from its sponsor/originator (Section 3 ). It then proceeds to analyse the instances where the insulation of the vehicle (and its assets) has been or can be put in jeopardy, no matter whether the legal device used corresponds to those traditionally envisaged (Section 4). Finally, it provides some tentative conclusions (Section 5).

\section{Securitization, conceptions of bankruptcy-remoteness and the debate on bankruptcy policy}

This section sets up the framework for the discussion. First, it addresses the rationale of insulating a pool of assets and/or cash flows as the basis for securitization, and other bankruptcy-remote transactions. Second, it distinguishes between conceptions of 'bankruptcy-remoteness' and specifies the subject-matter of the present study. Third, it situates the elements of bankruptcy-remoteness in the broader context of the debate on bankruptcy law.

\section{Securitization and other uses of bankruptcy-remote SPVs}

A securitization transaction normally involves a party (the 'sponsor') with a large portfolio of assets, such as a bank, who wants to exchange them for cash. In order to isolate and then transfer the risk of the assets, the sponsor will use a Special Purpose Vehicle, typically a corporation, partnership or trust with the narrow mandate of acquiring the assets and, then, of issuing securities that will be purchased by investors. The SPV will outsource the servicing and collection of proceeds to a 'servicer'; and the provision of credit and liquidity enhancement (both tasks often fall to the sponsor itself). Then, underwriters or placement agents (normally investment banks) acquire and place the notes, commercial paper or securities in the market. Finally, the transaction is normally subject to the evaluation of one (normally two) rating agencies (Moody's, 
Standard \& Poor's, or Fitch). Graphically:

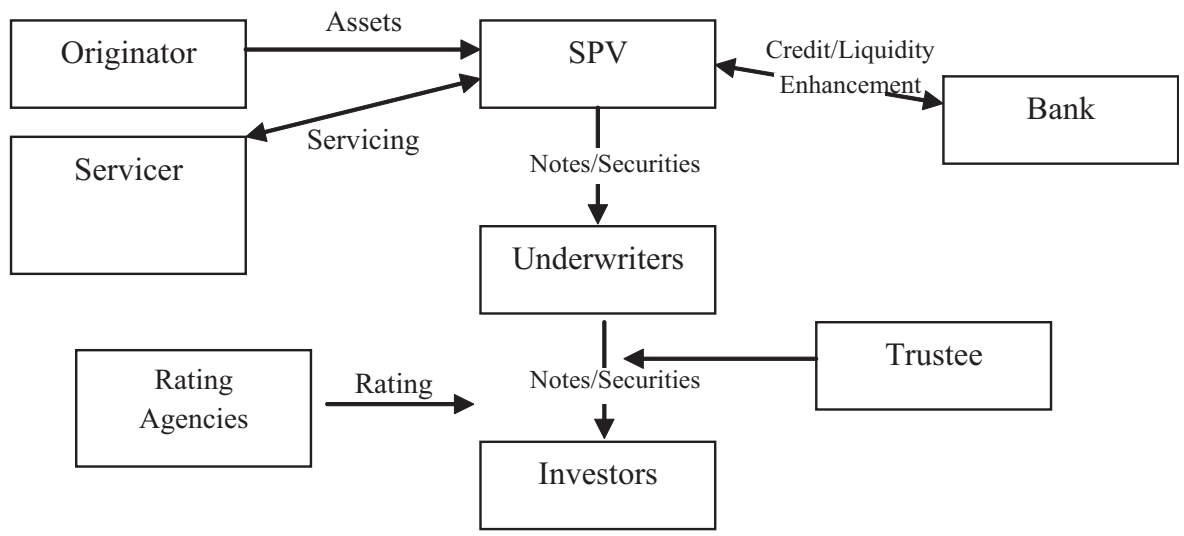

The described structure corresponds to a basic 'cash' securitization. In synthetic structures, the risk is transferred by means of derivatives contracts between the holder of the securitized assets and the SPV [the contract being a credit derivative, typically a Credit Default Swap (CDS)]. To fund its position, the SPV issues securities often called 'Credit Linked Notes' (CLN) divided in different tranches according to their seniority (super-senior, senior, mezzanine ... .). ${ }^{1}$

Although securitization has made them popular, the use of SPVs/SPEs can be useful in any context where specific assets or cash flows need to be insulated from other risks, especially those associated with the activity of the transaction sponsor. Asset finance transactions, for example, need to insulate a large asset (eg vessel or aircraft): the end user (typically, the carrier) does not normally acquire the asset but has a lease over it, a lease that is not granted by the manufacturer, but, rather, by a special purpose vehicle, or a chain of SPVs, whose purpose is to own the asset or hold a lease over it, and lease it down the chain; and get lease payments and upstream them to the lessor, banks or investors. ${ }^{2}$ In real estate finance, an SPV may be created to hold each real estate property, subscribe the loan and grant a security interest to the lender over the property, ${ }^{3}$ thereby insulating it from the risks of the developer or the sponsor. And, in mergers and acquisitions, vehicles are used in LBOs to be filled up with debt, and then acquire the target company. ${ }^{4}$

1 The proceeds obtained from investors are deposited in an account or invested in risk-free assets. Then, the sponsor makes periodical 'premium' payments to the SPV; who transfers them to investors, together with the interest from the risk-free assets. If a Credit Event (say, a substantial default, a drop in the levels of overcollateralization, etc.) occurs, the sponsor seizes control of the account/risk-free assets, whose risk the transaction tried to cover, and which are transferred to the SPV, which in turn holds them on behalf of the investors. If the sponsor defaults, investors (or their trustee) can themselves seize control over the assets. See David Ramos Muñoz, The Law of Transnational Securitization (OUP 2010) 168-70. See also The Bank of New York $v$ Montana Board of Investments, Party A, Party B [2008] EWHC 1594 (Ch).

2 Simon Hall, 'Transaction Structures' in Chris Boobyer (ed), Leasing and Asset Finance (4th edn, Euromoney 2003) 90-94.

3 William Seligman, 'Single Purpose Entities in US Real Estate Transactions: Are they worth the hassle?' (2006) 4(1) Brief Real Estate Finan 231-41.

4 Daniel S Riemer, 'Special Purpose Acquisition Companies: SPAC and SPAN or Blank Check Redux?' (2007) 85 Wash U L Rev 931-67. 
SPVs can also be used to insulate all the assets and flows pertaining to a specific project. In project finance transactions, it is customary to set up a vehicle that has legal rights over the project, and gets the funding directly from the bank syndicate, ${ }^{5}$ to shield the project from the contingencies of the sponsors (construction companies).

The use of SPVs/SPEs was much tainted by the Enron scandal, where such vehicles' properties were used for the wrong purposes: in appearance, Enron sold to investors a share in different specific projects, the risks and rewards of which would be insulated from those of Enron itself; but, in practice, investors acted like tools in a deliberate attempt to make-up Enron's risk exposures and get them off-balance sheet. ${ }^{6}$ SPVs do not have a pre-determined purpose, and can be put to use whenever a clear compartmentalization is needed to insulate them from bankruptcy. This makes it all the more important to understand the meaning of bankruptcy-remoteness.

\section{Conceptions of bankruptcy-remoteness: vehicle shielding and contracting-out bankruptcy}

The usefulness of SPVs rests on their fitness to insulate assets and/or cash flows from the wider risks of the sponsor. The real test for such insulation is bankruptcy: if upon bankruptcy the assets or flows are commingled with the assets/flows of the sponsor, the SPV loses its economic purpose. This has led to use the term 'bankruptcy-remote' to characterize SPVs and the transactions that use them. However, there is still much confusion because 'bankruptcy-remote' is a commercial term rather than a legal term. Perhaps the greatest effort to draw the legally significant elements out of it was done by Judge Schmetterer in the 2013 case of Re Doctors Hospital of Hyde Park Inc. ${ }^{7}$ In that case the issue at stake was the legitimacy of the vehicle as a 'normal' bankruptcy-remote SPV; which required that the nature of a bankruptcy-remote SPV be established first. In a lengthy analysis of evidence and legal sources - to which we cannot do justice here-the judge concluded that:

Although a 'bankruptcy remote entity' is not defined in the Bankruptcy Code or other statute, it is recognized in the business world and literature as a structure designed to hold a defined group of assets and to protect those assets from being administered as the property of a bankruptcy estate in the event of a bankruptcy filing. ${ }^{8}$

5 James Penrose, 'Special-Purpose Entities in Project Finance Transactions' (1996) 2(3) J Struct Finan 58-66.

6 William C Powers (chair), Report of Investigation by the Special Committee of the Board of Directors of Enron Corp (1 February 2002) (hereafter: Power's Report) 1-203.

7 Re Doctors Hospital of Hyde Park, Inc, 2013 WL 5524696 (Bankr ND Ill 2013). Previous to this case two others had been decided on the same bankruptcy. See Re Doctors Hospital of Hyde Park, Inc, 360 BR 787 (Bankr ND Ill 2007), affirmed in appeal by the district court in Paloian v LaSalle, 406 FSupp2d 299 (ND Ill 2007), but reversed in further appeal by the Court of Appeals of the Seventh Circuit in Paloian v LaSalle, 619 F3d 688 (2010). Other court decisions that have discussed the concept, see Re General Growth Properties, Inc, 409 BR 43, 49 (Bankr SDNY 2009); Re LTV Steel Co Inc, 274 BR 278, 280 (Bankr, ND Ohio 2001), or Roseton OL, LLC v Dynegy Holdings Inc, CA No 6689-VCP, 2011 Del Ch LEXIS 113 (Del Ch 29 July 2011) in the USA, or BNY Corporate Trustee Services Ltd v Eurosail-UK 2007-3BL plc and others [2010] EWHC 2005 (Ch), per Morritt J; BNY Corporate Trustee Services Ltd $v$ Eurosail-UK 2007-3BL plc and others (BNY Ltd v Eurosail plc (CA)) [2011] EWCACiv 227; or Re Golden Key Ltd (In Receivership) $v$ Re the Insolvency Act 1986 [2009] EWHC 148 (Ch) in the United Kingdom.

8 Re Doctors Hospital of Hyde Park, Inc, 2013 WL 5524696 (Bankr ND Ill 2013) at 203. 
The court then focused on the problem at stake (fraudulent transfers, re-characterization and veil piercing) and did not examine the fact that this concept encompasses, at least, two possible definitions; which are here characterized as 'basic' bankruptcy-remoteness, which emphasizes vehicle shielding (and where we will focus our efforts); and 'enhanced' bankruptcy-remoteness, which emphasizes the contracting out of bankruptcy proceedings.

1. The 'basic' conception of bankruptcy-remoteness is not too different from 'entity shielding' or 'affirmative asset partitioning' which are used to define corporate legal personality. ${ }^{9}$ The idea is that the partitioning of the assets of the corporation/vehicle and the assets of the sponsor/partner enhances the separate value of the partitioned assets. ${ }^{10}$ Separate legal personality provides these benefits, in the form of a claim by the vehicle's/corporation's creditors over the assets that has priority over the sponsor's/ partner's creditors. ${ }^{11}$

2. The exclusion of bankruptcy proceedings is also a priority when the proceedings would be those of the vehicle itself. This gives rise to a second conception, of 'enhanced' bankruptcy-remoteness, which can also be called 'bankruptcy-proof', which implies not only that the vehicle is insulated from the bankruptcy proceedings of the originator/sponsor or other transaction parties, but from every kind of bankruptcy proceedings regulated by statute. ${ }^{12}$

The important thing is to be aware that different persons can mean different things when they refer to 'bankruptcy-remote' entities or transactions, or to 'bankruptcy-remoteness' as a feat of those transactions. To be consistent with this precision, we choose the conception of 'vehicle shielding' as the subject matter of this article. Not only is 'vehicle shielding' the conception more typically associated with bankruptcy-remoteness; its underlying idea is also simpler (insulation between sponsor and vehicle) which makes it easier to connect policy and practice. Thus, 'vehicle shielding' will be the definition of bankruptcy-remoteness used in this article.

\footnotetext{
9 For a further analysis of the 'entity shielding' or 'affirmative asset partitioning' concept, see Henry Hansmann and Reinier Kraakman and Richard Squire, 'Law and the Rise of the Firm' (2006) 119 Harv L Rev 1335ff; Henry Hansmann and Reinier Kraakman, 'The Essential Role of Organizational Law' (2000) 110 Yale LJ 387. See also Reinier Kraakman and others, The Anatomy of Corporate Law. A Comparative and Functional Approach (hereafter: The Anatomy of Corporate Law) (2nd edn, OUP 2009 ) 6-7. 10 Kraakman and others (n 9) 10.

11 Cf Hansmann, Kraakman and Squire (n 9). Separate legal personality also involves a 'liquidation protection', meaning that no party (typically the sponsor) should be able to force the liquidation of the entity or its assets. See Hansmann and Kraakman (n 9) 411-13.

12 The point is illustrated by the distinction made in the Eurosail case between 'insolvency-remoteness' (ie avoiding the possibility of the vehicle becoming insolvent) and 'bankruptcy-remoteness' (ie avoiding the possibility of the vehicle entering proceedings resulting from the insolvency). BNY Corporate Trustee Services Ltd v Eurosail-UK 2007-3BL plc and others [2010] EWHC 2005 (Ch), per Morritt J; BNY Corporate Trustee Services Ltd v Eurosail-UK 2007-3BL plc and others (BNY Ltd v Eurosail plc (CA)) [2011] EWCACiv 227. See also Re Golden Key Ltd (In Receivership) $v$ Re the Insolvency Act 1986 [2009] EWHC 148 (Ch) at 47. That notion is also present in the witness testimony of Soleimani recorded in Re Doctors Hospital of Hyde Park, Inc, 2013 WL 5524696 (Bankr ND Ill 2013) at 149, according to whom 'a bankruptcy remote entity is intended to have a lower chance of having its assets administered in a bankruptcy case. The result is accomplished by ensuring that (a) the SPE has no other business other than that which is defined and permitted; and (b) there are provisions in the entity's formation documents which make it more difficult for the SPE itself to file a voluntary bankruptcy'. The fact that the case concerned issues of vehicle shielding probably resulted in the court's disregard towards the second conception.
} 


\section{Securitization and SPVs in context: the broader debate on bankruptcy policy and bankruptcy-remote structures as a pivotal case}

Academic debate on bankruptcy law in the USA has been shaped in recent times by the confrontation between proceduralist/contractarian, and judicialist/traditionalist views. Proceduralist/contractarian scholars argue that the life and death of companies should be dictated by the Darwinian dynamics of the marketplace, and thus the law should not promote the 'rescue' of companies, but, rather, give effect to pre-insolvency contractual arrangements; the debate should be about the best way to give effect to those arrangements. ${ }^{13}$ Judicialist/traditionalist scholars argue that contractarian views are elegant in theory yet unfeasible in practice, given the nigh impossibility of coordinating so many different creditors; $^{14}$ and, even if a contractarian proposal could be implemented, and it actually maximized the realization value for 'all' creditors, its superior efficiency when bankruptcy policy is considered in isolation should be weighed by other socially desirable goals (eg job protection, impact on communities, etc). ${ }^{15}$

The different perspectives translate into diverging views on asset partitioning (which can be extrapolated to vehicle shielding). Generally, contractarians support the protection of the pre-insolvency status quo, especially the interest of secured creditors, who should be given a leading role in the bankruptcy process to shape its quasi-contract solutions. ${ }^{16}$ Critics argue that such solutions, rather than maximizing wealth, simply re-distribute it from unsecured non-adjusting creditors to secured creditors. ${ }^{17}$

The past focus of this debate has been on whether bankruptcy law should respect security interests: some justified the efficiency of security interests, others disputed the efficiency arguments as unconvincing; ${ }^{18}$ others argued that, absent empirical evidence,

13 Barry Adler, 'Bankruptcy Primitives' (2004) 12 Am Bankr Inst L Rev 219-44; Adler, 'Financial and Political Theories of American Corporate Bankruptcy' (1993) 45 Stan L Rev 311-46; Adler, 'A Theory of Corporate Insolvency' (1997) 72 NYU L Rev 343, 382-434; Douglas G Baird, 'Bankruptcy's Uncontested Axioms' (1999) 108 Yale LJ 573-99;Douglas G Baird and Robert K Rasmussen, 'The End of Bankruptcy' (2002) 55 Stan L Rev 751-89; Lucian Arye Bebchuk, 'A New Approach to Corporate Reorganizations' (1988) 101 Harv L Rev 775; Thomas H Jackson, 'Bankruptcy, Non-Bankruptcy Entitlements, and the Creditors' Bargain' (1982) 91 Yale LJ 857; Robert K Rasmussen, 'Debtor's Choice: A Menu Approach to Corporate Bankruptcy' (1992) 71 Tex L Rev 51; Robert K Rasmussen, 'An Essay on Optimal Bankruptcy Rules and Social Justice' (1994) 1 U Ill L Rev 42; Alan Schwartz, 'A Contract Theory Approach to Business Bankruptcy' (1998) 101 Yale LJ 1807; Steven L Schwarcz, 'Rethinking Freedom of Contract: A Bankruptcy Paradigm' (1999) 77 Texas L Rev 515-604.

14 Elizabeth Warren and Jay Lawrence Westbrook, 'Contracting out of Bankruptcy: An Empirical Intervention' (2005) 118 Harv L Rev 1197, 1201, 1253; Jay Lawrence Westbrook, 'The Control of Wealth in Bankruptcy' (2004) 82 Tex L Rev 795, 859-62.

15 Elizabeth Warren, 'Bankruptcy Policy' (1987) 54 U Chi L Rev 775, 785-89.

16 Baird and Rasmussen (n 13). To avoid coordination problems, special control rights must be given to a restricted number of creditors, typically secured creditors. See Westbrook (n 14) 806-20. See also Bebchuk (n 13) 775ff; Adler (n 13) 327ff.

17 A good overview of the debate is provided in Westbrook (n 14) 838-41. See also Lynn Lopucki, 'Contract Bankruptcy: A Reply to Alan Schwartz' (2000) 109 Yale LJ 317. Critics of secured credit have argued that the increase in control and security by the secured creditor must be matched by a proportional decrease in the value of collateral for unsecured creditors, which should result in an adjustment of their prices of credit. Thus, it switches the value from the debtor towards the secured creditor (partially, if, in addition to the increase in the cost of funding by unsecured creditors, the security also brings a decrease in the cost of funding from secured creditors).

18 The efficiency of security rights has been disputed since the early days of economic analysis of law. See Thomas H Jackson and Anthony T Kronman, 'Secured Financing and Priorities among Creditors' (1979) 88 Yale LJ 1143, who justified the overall efficiency gains on the basis of monitoring costs. This conclusion was contested by Alan Schwartz, 'Security Interests and Bankruptcy Priorities: A Review of Current Theories' (1981) 10 J Leg Stud 9-14; Alan Schwartz, 'The Continuing Puzzle of Secured Debt' (1984) 37 Vand L Rev 1055-9. See also James J White, 'Efficiency Justifications for Personal Property Security' (1984) 37 Vand L Rev 473. 
the argument in favour of security interests is one of custom (security interests are protected because the market uses them); ${ }^{19}$ and others have argued against security interests' full priority in bankruptcy. ${ }^{20}$

Since bankruptcy-remote transactions act as an enhanced substitute for security interests by using vehicle shielding to insulate the transaction's cash flows, the broader views have been replicated in this narrower context, albeit with a worrying lack of specificity. Some scholars, such as LoPucki, see the problem from the perspective of nonadjusting unsecured creditors, and regard securitization and SPVs as a means to disintegrate the bankruptcy estate, and transfer wealth to privileged creditors ${ }^{21}$ (thus, solely in light of the danger it poses). Others, such as Bebchuk and Fried, see that SPVs could be used as a way to circumvent a regime of partial priority in bankruptcy (thus, as a substitute for security interests); but dismiss the potential threat, arguing that (1) SPVs tend to insulate non-operating assets; (2) they are expensive to establish; and (3) riskaverse investors will be unwilling to lend funds to SPVs whose originating companies are at risk of bankruptcy, since there would be a material risk of being drawn into a bankruptcy proceeding should the parent file for bankruptcy. ${ }^{22}$

Those arguments, however, were made before securitization became widespread, and evolved into more sophisticated forms, such as whole-business securitization (where operating and non-operating assets are transferred) and before there were any court decisions, or statutory reforms took place. Securitization can no longer be treated as a 'borderline', or 'marginal' case, and be dismissed for its lack of importance, or painted in broad brushstrokes as a negative innovation. It should, rather, be treated as a 'pivotal' case, where the tension between specific solutions reflects a more profound disagreement about the goals, policies or doctrines of bankruptcy law. ${ }^{23}$

The widespread use of bankruptcy-remote transactions as an enhanced version of security interests makes the conclusion about the treatment of vehicle shielding fundamental to establishing the balance between privileged and general creditors in the law. At the same time, this importance makes it more difficult to seek one-size-fits all solutions, which could either disrupt credit markets (if bankruptcy-remote transactions are seen in solely negative terms) or

19 Homer Kripke, 'Law and Economics: Measuring the Economic Efficiency of Commercial Law in a Vacuum of Fact' (1985) 133 U Pa L Rev 929. The other recurring argument is the need to limit the debtor's potential for opportunistic behaviour. See George G Triantis, 'Secured Debt Under Conditions of Imperfect Information' (1992) 21 J Leg Stud 225; Saul Levmore, 'Monitors and Freeriders in Commercial and Corporate Settings' (1982) 92 Yale LJ 49. Such theories, however, do not take into account that a secured creditor can behave opportunistically as well. See Westbrook (n 14) 838, fn 173.

20 Lucian Ayre Bebchuk and Jesse M Fried, 'The Uneasy Case for the Priority of Secured Claims in Bankruptcy' (1996) 105 Yale LJ 857-934; Bebchuk and Fried, 'The Uneasy Case for the Priority of Secured Claims in Bankruptcy: Further Thoughts and a Reply to Critics' (1997) 82 Cornell L Rev 1289-348.

21 Bankruptcy-remote structures with SPVs are characterized by LoPucki as an example of 'judgment-proof strategies, which can render debtors immune to bankruptcy principles, to the extent that 'a company potentially could divest itself of all of its assets, yet continue to use all of those assets in the continued operation of its business', drawing the distinction between 'entities that own things and entities that do things'. See Lynn LoPucki, 'The Death of Liability' (1996) 106 Yale LJ 1-92, 25, 28. See also LoPucki, 'The Unsecured Creditor's Bargain' (1994) 80 Va L Rev 1887-966.

22 Bebchuk and Fried (n 20) 1341.

23 For a distinction between 'borderline' and 'pivotal' cases, see Ronald Dworkin, Law's Empire (Hart Publishing 1986), reprinted 2004, 41-43. 
unfairly deprive unsecured creditors of an opportunity to receive their due (if bankruptcyremote transactions are invariably protected as a matter of policy).

Furthermore, there is now information in statutory law and case law to start drawing conclusions, beyond the theoretical, about how the interests of the debtor and unsecured creditors and the interests of secured creditors are balanced. The way these tensions are resolved in practice can have important implications beyond the field of bankruptcy-remote transactions.

\section{Threats to vehicle shielding in theory}

The threats to vehicle shielding that have traditionally been the subject matter of discussion can be divided between the threats to the asset transfer (in the form of avoidance and re-characterization); and the threats to the separation of patrimonies between the vehicle and the originator/sponsor (in the form of substantive consolidation). These threats will be examined in the following two subsections.

\section{Threats to the asset transfer: avoidance and re-characterization}

The first concern of parties in a bankruptcy-remote transaction is about the possibility that the transfer of assets that takes place in the transaction is not undone by a court. The riskiest scenario is that of the transferor's bankruptcy, where the trustee/administrator could resort to two avenues: avoidance (in case of fraudulent conveyance) and re-characterization (if the sale has the elements of a secured transaction). These two avenues will now be discussed in turn.

Normally a transaction can be unwound in cases where the debtor has not received 'fair value' in the exchange. ${ }^{24}$ In the USA, this rule, known as 'constructive fraud', constituted a specific application of the policy against fraudulent conveyances; ${ }^{25}$ but soon replaced it as the general rule. Those who have addressed the issue have tended to dismiss its relative importance in securitization, given that the consideration the transferor receives for the assets is typically a 'fair value'. ${ }^{26}$

However, scholars such as Kettering have recently argued that, at least in the USA, the law of fraudulent transfers can also apply without the requirements of inadequate consideration or 'fraudulent intent' or 'fraud'; and that this more open version of the doctrine (the so-called 'nonhindrance' policy variant) ${ }^{27}$ could easily put bankruptcyremoteness in jeopardy.

The analysis supporting this conclusion is deep and attentive to detail; and its underlying message is sound: that no transaction, despite its widespread use and critical

24 See s $§ 548(a)(1)(B)$ Bankruptcy Code; ss $\S \S 4(a)(2), 5(a)$ Uniform Fraudulent Transfer Act.

25 This operated in cases where a transfer was made with the 'intent to delay, hinder or defraud creditors'. The origins of the rule are in Statute of 13 in Elizabethan England. See Kettering (n 27) 1585.

26 Steven L Schwarcz, Structured Finance: A Guide to Asset Securitization Third edition Practising Law Institute (PLI), 2004, at Section 4.7, Jason Kravitt, Securitization of Financial Assets (Aspen Publishers 1995) §5.05[H].

27 Kenneth Kettering, 'Securitization and its Discontents: the Dynamics of Financial Product Development' (2008) 29 Cardozo L Rev 1553-728. Kettering refers to the cases of Benedict $v$ Ratner 268 US 353 (1925); Dean v Davis 242 US 438 (1917); Empire Lighting Fixture Co v Practical Lighting Fixture Co, 20 F2d 295 (2d Cir 1927) (L Hand, J); Klein v Rossi (Re Midwest SS Agency, Inc), 251 F Supp 1 (EDNY 1966); Shapiro v Wilgus 287 US 348 (1932). The view was subject to heated criticism, especially from professor Thomas Planck. See 'Sense and Sensibility in Securitization: A Prudent Legal Structure and a Fanciful Critique' (2009) 30 Car L Rev 617. The attack was followed by a reply. See Kenneth Kettering, 'Pride and Prejudice in Securitization: a Reply to Professor Planck' (2009) 30 Cardozo L Rev 1977. 
importance to financial markets, should be beyond (legal) reproach. However, there are two main problems with the line of argument employed: first, the cases used to support it were decided under quite specific circumstances, and it is hard to draw a common rationale that applies to all of them and bankruptcy-remote transactions. ${ }^{28}$

Second, absent a more specific common rationale, their common denominator is the idea that fraudulent transfer law allows bankruptcy courts to use a 'policy analysis' when making the decision to set aside a transaction that prejudices creditors. But then, it would be hard to draw the boundaries of this doctrine, which would come perilously close to unfettered judicial discretion. And, if that were the case, the question is why should one stop at securitization. If whole categories of transactions can be signalled out and undone pursuant to a policy analysis, there is nothing intrinsically more harmful in securitization than in factoring, secured loans, asset sales or corporate spin-offs. The question is not whether transfers to SPVs can be undone, but 'what else' should the courts require to undo them. To this question the broad analysis has no answer, and the courts have so far been shy of deciding on pure policy grounds. Thus, absent special circumstances (such as an unfair price, suspicious timing or other elements not determined by the transaction as such), one must conclude that fraudulent conveyance is not a risk in practice for bankruptcy-remote transactions.

This impression is confirmed by the cases that have decided on the issue. In Roseton OL, LLC v Dynegy Holdings, ${ }^{29}$ Delaware's Court of Chancery considered the plaintiffs' (Roseton OL LLC and Danskammer OL, LLC) motion seeking to temporarily restrain the closing of a reorganization transaction pursuant to which defendant Dynegy Holdings, Inc. (DHI) would transfer its coal- and gas-fired power plants from existing subsidiaries to new bankruptcy-remote subsidiaries that would be indirectly controlled by a whollyowned subsidiary of DHI, a move that would guarantee a new credit facility for the bankruptcy-remote entities.

The court dismissed the request for a temporary restraining order, holding, among other things, that the reorganization did not amount to a fraudulent transfer: the reorganization would not transfer any value from its corporate structure, would improve DHI's liquidity (with the new credit facility) and DHI was not insolvent. Thus, the

28 In Shapiro $v$ Wilgus 287 US 348 (1932) the US Supreme Court set aside a transaction by which the debtor set up a company, to which he transferred all his assets in exchange for his shares, and which he made enter receivership. Kettering draws the conclusion that, in those cases where the transaction entails a diminution of the debtor's liquid assets, the transaction is vulnerable under the 'nonhindrance' perspective of the law of fraudulent transfers; and that such a conclusion poses a threat to securitization. See Kettering (n 27) 1601-3. But the consideration the sponsor receives in exchange for assets is more liquid assets (cash), not the shares of the SPV. Also, Shapiro involved an attempt by an individual to opt into a regime like receivership; which was then available only to corporations, an idea that was expanded in further cases such as Sherman $v$ Collins (Re Collins), 75 F2d 62 (8th Cir 1934); Milwaukee Postal Bldg Corp v McCann, 95 F2d 948, 950 (8th Cir 1938) or re Francfair, Inc, 13 F Supp 513 (SDNY 1935), where assets were transferred to an entity that benefited from bankruptcy provisions unavailable to the transferor, thereby giving rise to the 'good faith' principle in bankruptcy filing. ibid 1604-5. In addition, there were two other important factors. First, the fact that the transfers were made upon an impending situation of financial distress; which emphasizes timing, not the transfer itself. Second, the replacement of one entity by another (the so-called 'new debtor syndrome') with the transfer of all or almost all, of the debtor's assets. It is hard to see the parallel with securitization (or other bankruptcy-remote transactions) unless the transaction involves all the company's assets and is done on the verge of insolvency, circumstances that might be simultaneous to the transaction, but enjoy no cause-effect relationship with it.

29 Roseton OL, LLC v Dynegy Holdings Inc, CA No 6689-VCP, 2011 Del Ch LEXIS 113, (Del Ch 29 July 2011). 
request could not succeed in the absence of evidence that DHI had an actual intent to hinder the plaintiffs' ability to collect payment if the subsidiary-lessees defaulted. ${ }^{30}$

The issue was also examined in the Doctors Hospital saga, where a bankruptcy court and a district court rejected the existence of a fraudulent transfer to a bankruptcy-remote special purpose vehicle. ${ }^{31}$ The Court of Appeals for the Seventh Circuit vacated the judgment of the District Court with instructions to remand the case to the Bankruptcy Court again. But in doing so it did not hold that there had been a fraudulent transfer, but that a previous decision was needed on whether the vehicle had separate existence. ${ }^{32}$ The structure of the transaction and vehicle will be addressed later, as their implications are more important for the purposes of veil piercing/substantive consolidation. ${ }^{33}$ On the present issue (transaction avoidance), the bankruptcy court found that there had been no fraudulent transfer, because the hospital received consideration for the receivables (in the form of a cancellation of debts) and the transaction was executed at arm's length. ${ }^{34}$ It held this despite the fact that the SPV was fully owned by the hospital and the hospital's owner (Desnick): the court accepted the entities' separate representation as evidence of arm's length, and referred to precedents that relied on directors' ability to 'change hats' in representing the two corporations separately. ${ }^{35}$

We turn now to re-characterization. Conventional wisdom on bankruptcy-remote transactions suggests that, rather than transaction avoidance for fraudulent transfer, recharacterization of the asset transfer as a secured transaction is a more clear and present danger. ${ }^{36}$ The distinction is relevant for bankruptcy law: in some countries security interests (but not sales) are subject to registration, and, absent this, they can be invalidated; ${ }^{37}$ and, in other countries, enforcement of secured transactions is subject to an automatic stay, and cash proceeds from the transferred receivables can be used by the 'debtor in possession' provided he can provide for adequate protection of the

30 ibid. The catch, however, was that, in this case, the assets would not leave DHI's control because the bankruptcy-remote subsidiaries would be indirectly controlled by it, unlike a case where the assets were transferred in exchange for money or other consideration to non-controlled SPVs (as in a securitization). The interest of the case is to see that the court considered the bankruptcy-remote nature of the entities as a non-irrelevant factor in assessing the existence of a fraudulent transfer.

31 Doctors Hosp of Hyde Park, Inc v Desnick, et al (Re Doctors Hosp of Hyde Park, Inc), 360 BR 787, 811-12 (Bankr ND Ill 2007); LaSalle Bank NA v Paloian, 406 BR 299, 366 (ND Ill 2009).

32 Paloian v LaSalle Bank, NA, 619 F3d 688, 695, 696 (7th Cir 2010).

33 See 'Threats to the separation between sponsor and vehicle: substantive consolidation' section.

34 Re Doctors Hospital of Hyde Park, Inc, 2013 WL 5524696 (Bankr ND Ill 2013).

35 ibid 216, citing Orchard Urban Limited P'ship v Harry Rosen, Inc, 904 NE2d 1050, 1061 (Ill App 2009) and Forsythe v Clark USA, Inc, 864 NE2d 227, 239 (Ill 2007) (veil piercing cases).

36 See Thomas E Plank, 'The True Sale of Loans and the Role of Recourse' (1991) 14 Geo Mas U L Rev 287; 'The Security of Securitization and the Future of Security' (2004) 25 Car L Rev 1655; Robert D Aicher and William J Fellerhoff, 'Characterization of a Transfer of Receivables as a Sale or a Secured Loan Upon Bankruptcy of the Transferor' (1991) 65 Am Bankr LJ 186-87ff; Lois R Lupica, 'Asset Securitization: The Unsecured Creditor's Perspective' (1998) 76 Tex L Rev 595; Stephen J Lubben, 'Beyond True Sales: Securitization and Chapter 11' (2004-2005) 1 NYU J L \& Bus 94; Vijay Selvam, 'Recharacterisation in "True Sale" Securitizations: The “Substance over Form” Delusion' Oct (2006) J Bus L 637; Alan Berg, 'Recharacterisation after Enron' May (2003) J Bus L 216-18.

37 Such is the case in England. See Muñoz (n 1) 68. In the USA, even if the approach of Art 9 of the UCC is to require registration of all secured transactions, the assignment of receivables is equally subject to registration, no matter that it is done with purposes other than security. See \$9-109 (a) (3) UCC. 
secured party's interests. ${ }^{38}$ Comparative analysis, however, shows that re-characterization is more interesting as a topic of academic discussion than as a real threat to securitization.

(a) In England, the relevant elements to distinguishing a sale from a secured transaction were established by Rome J in Re George Inglefield Ltd: ${ }^{39}$ (i) the assignor's 'equity of redemption', ie the right to recover the collateral, absent in a sale; (ii) the assignor's right to the surplus in the sale of collateral to third parties and (iii) the assignee's right to claim against the assignor the difference if the collateral value is insufficient, all absent in a sale (recourse). ${ }^{40}$ The decision emphasized the 'risks-andrewards', rather than 'control' over the property.

This approach was further refined in Orion Finance $L t d^{41}$ with several important points. (i) One, to ascertain the parties' will the court took two consecutive steps: first it considered the existence of a 'sham'; and only once this had been discarded, did the court consider whether the parties' real intention corresponded to the denomination given in the contract language. For English courts, a sham will be immediately excluded when the documents contemplate the contents of the transaction and it is not necessary to resort to extrinsic means of evidence. ${ }^{42}$ Thus, unlike other courts, for whom the sham analysis is done together with the interpretation of the parties' will, it is only a first step in the court's process to find the truth, and thus it is possible for a transaction not to be a sham, and still be re-characterized pursuant to a substance-over-form analysis of the parties' intention. ${ }^{43}$

(ii) To ascertain that intention requires a careful balancing between the 'language' of contract provisions, on one hand, and their 'legal effect', on the other hand: even though the substance of the agreement is in the terms used by the parties, those must be characterized pursuant to their intended legal effect; so that, if that effect is inconsistent with the language, language must yield. ${ }^{44}$

38 See respectively ss 11 USC $\S 362(a)(1)$, (6) (2006) (automatic stay); United Say. Ass'n of Texas $v$ Timbers of Inwood Forest Assocs, 484 US 365, 382 (1988) (non-accrual of interests to the undersecured); and 11 USC $\S 506$ (b) (2006) (accrual of interest to the oversecured); and 11 USC $\S 363$ (a), (c)(2), (e) (2006) (use of cash proceeds as 'cash collateral' by the debtor). See also Planck (n 27) 622. Needless to say, despite the purported ability to protect the secured party's interests, the latter would prefer that cash proceeds were transferred to him, or be untouchable by the debtor at the very least.

39 Re George Inglefield Ltd [1933] Ch 1.

40 ibid.

41 Orion Finance Ltd v Crown Financial Management Ltd [1996] BCC 621.

42 The court relied on Welsh Development Agency v Export Finance Co Ltd [1992] BCC 270.

43 The decision on a 'sham' involves a definite judgment of 'impropriety' over the parties' aim to conceal the actual transaction. In civil law countries, such as Spain, the courts, prompted by the academic debate, have tried to move away from an approach based on the parties' intention (and thereby from a moral judgment of impropriety) towards an objective approach based on the causa, so that the 'sham', or 'simulación' doctrine applies when the apparent arrangement does not have any purpose at all (absolute simulación) or its purpose corresponds to a different causa than that signalled by the parties (relative simulación). See Luis Díez Picazo, Fundamentos de Derecho Civil Patrimonial (Sexta edición) vol I Introducción. Teoría del Contrato (Tecnos 2007) 221-22, 281. Yet the judgment of impropriety becomes an express (and major) element of the test under tax law. See Violeta Ruiz Almendral, El Fraude a la Ley Tributaria a Examen (Aranzadi 2006) 114-15.

44 'Once the documents are accepted as genuinely representing the transaction into which the parties have entered, its proper legal categorisation is a matter of construction of the documents. This does not mean that the terms which the parties have adopted are necessarily determinative. The substance of the parties' agreement must be found in the language they have used; but the categorization of a document is determined by the legal effect which it is intended to have, and if when properly construed the effect of the document as a whole is inconsistent with the terminology which the parties have used then their ill-chosen language must yield to the substance.' Millett LJ in Orion Finance Ltd $v$ Crown Financial Management Ltd [1996] BCC 621, at 627. 
The question, then, lies in determining what must be understood as 'inconsistent', since there is no single element that results per se in re-characterization. ${ }^{45}$ The court thus emphasized the need to interpret the agreement as a whole, and even to go beyond that, and understand the whole contractual 'architecture' (beyond the specific agreement that gives effect to the transfer). In Orion, the architecture suggested that the assignment was done as part of a security package to finance the acquisition of computer equipment. ${ }^{46}$ This conclusion was reinforced by the use of language suggesting the existence of a security right, ${ }^{47}$ and led to the conclusion that the agreement had to be re-characterized.

The court's holding in Orion remains the exception, however, and English courts rely on the contract denomination. Furthermore, the elements considered decisive in Orion are not normally present in securitization transactions, where arrangements are introduced to separate the transaction assets from the assets of the sponsor/originator, and prevent the latter from interfering with them.

(b) Other common law courts, such as those in Canada, have, like their English counterparts, adopted an approach focused on the parties' intention. In the important decision of Metropolitan Widows, ${ }^{48}$ the court classified the transfer of receivables by BC Tel to RAC Trust (SPV) under a securitization transaction as a true sale. Even though the court laid out the factors relevant to classifying the transaction, and stressed the need to make a substance over form analysis, it also emphasized that the factors used were not a mere mechanical checklist, and that the most important was the parties' intention. ${ }^{49}$ This led the court to uphold the transfer as a 'sale'.

An even more formalistic assessment, which assimilated the 'parties' intention' to the documents' language and form was done in the case Incorporated $v$ Yun Choy Limited and the Standard Chartered Bank (Hong Kong) Limited, decided by Hong Kong courts, where,

45 Lord Wilberforce in Lloyds \& Scottish Finance Ltd v Cyril Lord Carpets Sales Ltd [1992] BCLC 609 stated that not even a fullblown right of redemption for the assignor would, in itself, determine the existence of a secured transaction.

46 Orion acquired computer equipment, then leased it to Atlantic, which, in turn, leased it to its customers (in this case, Crown). Atlantic assigned to Orion all the receivables arising from its clients' future payments, which, the court held, was an ancillary agreement (part of Atlantic's security package) not a true sale. In order to do that, however, Lord Millet disregarded a clause providing for adjustments depending on whether the payments from Crown to Atlantic were higher or lower than those from Atlantic to Orion, for being 'extrinsic' to the analysis. See Millett LJ in Orion Finance Ltd v Crown Financial Management Ltd [1996] BCC 621 , at 628 .

47 The assignment clause contained in the lease agreement indicated that: 'The hirer (Atlantic), as security for its obligations hereunder, shall assign to the owner (Orion) under the terms of a deed of assignment all moneys now or hereafter to become payable to the hirer under the lease to the intent that they be charged with the payment of all moneys now or hereafter owing to the owner under this agreement except that such a security and assignment will not encumber or extend to [excepted payments].' In the words of Otton LJ, 'The critical phrases are "as security for its obligations hereunder", "they be charged", "such security" and "encumber". The use of these phrases in this context is in my judgment only consistent with an assignment by way of security and inconsistent with an absolute assignment.' See Otton LJ en Orion Finance Ltd v Crown Financial Management Ltd [1996] BCC 621, en 631 .

48 Metropolitan Toronto Police Widows and Orphans Fund v Telus Communications Inc (2005), 75OR (3d) 784 (CA).

49 Among the factors outlined by the court were the intention of the parties; the transfer of ownership risk and the level of recourse; the ability to identify the assets sold; the ability to calculate the purchase price and whether the return to the purchaser will be more than its initial investment and calculated yield on such investment; the right to retain surplus collections; any right of the Originator to repurchase the assets; the responsibility for collection of the accounts receivable; any ability of the Originator to extinguish the purchaser's rights from other sources other than the collection of the receivables. Yet the court held the main purpose of the exercise was to 'give legal effect to the intention of the parties as expressed in the language of the agreement'. Metropolitan Toronto Police Widows and Orphans Fund v Telus Communications Inc (2005), 75OR (3d) 784 (CA) at 796. 
despite the numerous elements that kept the assets' risk in the transferor's hands, ${ }^{50}$ the court found that the transfer was a 'sale'.

(c) Unlike these jurisdictions, the USA is characterized by a greater variety (and thus uncertainty) of approaches. In general, an important difference is that courts following a 'substance over form' approach are keener to focus on the economics of the transaction directly, rather than indirectly, as a means to ascertain the parties' intention. In Major's Furniture, ${ }^{51}$ a retail furniture company (assignor) sold the receivables to a financing company (assignee) under terms that left all the risk of default to the furniture company. ${ }^{52}$ The furniture company claimed from the assignee the right to the surplus, and the answer to the question depended on the 'true sale' nature of the transfer. ${ }^{53}$ It is important to note that the decision was adopted pursuant to article 9 of the UCC, which regulates both secured transactions and receivables assignments, and equates them for purposes of registration, and thus facilitates a more functional (ie less formalistic) approach. $^{54}$

The court held that the courts are not subject to the parties' nomenclature, the form of the contract, the name given to it by the parties or the form of words. ${ }^{55}$ In Major Furniture, the existence of recourse would not, in itself, suffice to classify the transaction as security, but the court also considered that the assignor had retained all conceivable risk associated to the receivables; and the assignee had unilaterally modified the financing conditions, meaning that the assignee itself treated the transaction as a secured credit line. ${ }^{56}$ All in all, the difference with other common law countries was not so much in the result, but in the approach, as the court stated that 'the question for this court then is whether the nature of the recourse, and the true nature of the transaction are such that the legal rights and economic consequences of the agreement bear a great similarity to a financing transaction or to a sale'. ${ }^{57}$

50 [2012] 1 HKLRD 396. The company retained the risk of non-repayment of debt by its customers, it had a right to the surplus of the receivables, and, in case the amount received from the receivables fell short, the bank could recover the balance from the company.

51 Major's Furniture Mart Inc v Castle Credit Corporation Inc et al 602 F2d 538 (1979).

52 El acuerdo de las partes preveía que la empresa de muebles procedería, de vez en cuando, a 'vender' créditos, pero que dicha venta sería 'con recurso' contra la vendedora. Además, la vendedora debía garantizar que los créditos se correspondían con una orden de compra o un contrato ya cumplido por ella, mientras que la compradora podía negarse a adquirir los créditos. La compradora pagaría a la vendedora el importe de los créditos menos un 15\% de descuento, y un 10\%, como reserva por créditos impagados. La vendedora, además, se comprometía a recomprar los créditos que permaneciesen impagados durante más de 60 días, recompra efectuada no al precio de compra (importe-15\% to 10\%) sino a un precio consistente en el importe más gastos de cobro o de otro tipo.

53 The Uniform Commercial Code, applicable in Pensylvania, gives, as a default rule, the right to surplus to the assignee in case of 'sale' of receivables, and to the assignor, in case of sale for the purposes of security. See Major's Furniture Mart Inc v Castle Credit Corporation Inc et al 602 F2d 538 (1979) at 543-44.

54 Roy Goode, Goode on Legal Problems of Credit and Security (Sweet \& Maxwell 2008) §1-04, 4-5.

55 The court referred to cases such as Re Joseph Kanner Hat Co, Inc, 482 F2d 937 (2d Cir 1973); Kelter v American Bankers' Finance Co, 306 Pa 483, 160 A 127 (1932), o Lyon v Ty-Wood Corporation, 212 PaSuper 69, 239 A2d 819 (1968).

56 Major's Furniture Mart Inc v Castle Credit Corporation Inc et al 602 F.2d 538 (1979) at 543-44. The court was also careful to distinguish between warranties of collectability and warranties as to quality or validity. The presence of warranties as to quality or validity might be consistent with true sale treatment, ibid 543. See also Lifewise Master Funding v Telebank, 374 F3d 917, 925 (10th Cir 2004), which held that, to establish the 'true sale' nature of a transfer when a transferee has a right of recourse, the court should consider the nature of the alleged recourse.

57 Major's Furniture Mart Inc v Castle Credit Corporation Inc et al 602 F2d 538 (1979) at 545. 
Such economic analysis was also present in later cases, such as Endico Potatoes, ${ }^{58}$ where, in addition to the emphasis on substance, regardless of the 'label attached to the transaction', the court indicated that 'The root of all of these factors is the transfer of risk' (an economic concept). ${ }^{59}$ Yet it is arguable whether such an economic approach was used as a legal or a rhetorical device, since the key element in re-classifying the assignee's right as one of security was the reference, in the contract language, where the provider of funding indicated its being 'pleased to confirm the terms and conditions under which we shall make loans and advances to you upon the security of your accounts receivable'. ${ }^{60}$

The other factor that was considered in some isolated instances as relevant to determine the existence of a secured loan, and not a sale, was the continuous involvement of the assignor through the servicing of the receivables. But cases where the transfer was re-characterized normally involved other elements, such as the non-notification of rights to the account debtor and the retention of rights to ask the account debtor for price adjustments, the commingling of funds or the existence of recourse; ${ }^{61}$ whereas other courts have rejected re-characterization as a loan when the arrangement included a separate collection fee. ${ }^{62}$

In Doctors Hospital, where re-characterization was considered in the context of a bankruptcy-remote transaction, the bankruptcy court concluded in 2013 that the transfer of receivables from the hospital to the vehicle was a 'sale', despite it being done under a 'true contribution' scheme (where the assignor received the vehicle's equity, rather than a cash price) because the agreement did not provide recourse by the vehicle to the Hospital with respect to the receivables if the underlying obligors did not pay, nor did it 'permit or require the Hospital to repurchase or substitute other receivables or property if the obligors did not pay'. ${ }^{63}$

It is important to stress that the case had been remanded to the bankruptcy court by the Court of Appeals of the Seventh Circuit, and the bankruptcy court was asked to examine whether the vehicle complied with the requirement that it should 'manage its own assets', 64 a stringent standard, in light of the fact that the SPV in that case, like many SPVs, had no employees or economic activity. However, the bankruptcy court found that this requirement was complied with, since the Hospital had notified debtors of the

\footnotetext{
58 Endico Potatoes, Inc v CIT Group/Factoring, Inc 67 F3d 1063; 1066-67 (2d Cir 1995).

59 The court continued: 'Where the lender has purchased the accounts receivable, the borrower's debt is extinguished and the lender's risk with regard to the performance of the accounts is direct, that is, the lender and not the borrower bears the risk of nonperformance by the account debtor. If the lender holds only a security interest, however, the lender's risk is derivative or secondary, that is, the borrower remains liable for the debt and bears the risk of non-payment by the account debtor, while the lender only bears the risk that the account debtor's non-payment will leave the borrower unable to satisfy the loan.' See Endico Potatoes, Inc $v$ CIT Group/Factoring, Inc 67 F3d 1063; 1066-67 (2d Cir 1995).

60 ibid.

61 Petron Trading Co v Hydrocarbon Trading \& Transport Co, 663 F Supp 1153, 1159 (ED Pa 1986) (in addition to servicing payments, the assignor prepared the invoices for contract payments, did not notify the account debtor, and reserved itself the right to ask the debtor for price adjustments); Southern Rock, Inc v B $\backsim B$ Auto Supply, 711 F2d 683, 685 (5th Cir 1983) (servicing and commingling of funds); Ables v Major Funding Corp, 82 BR 443, 448 (Bankr SD Tex 1987) (servicing, commingling and recourse).

62 Bear $v$ Coben (Re Golden Plan of Calif, Inc), 829 F2d 705, 709 (9th Cir 1986).

63 Re Doctors Hospital of Hyde Park, Inc, 2013 WL 5524696 (Bankr ND Ill.2013).

64 Paloian v LaSalle Bank, NA, 619 F3d 688 (7th Cir 2010).
} 
transfer, lacked any authority to modify, in its own name, the terms of the financing between the vehicle and the Daiwa-the bank that had extended the loan to it (a loan backed by the receivables) — there was no evidence of commingling, a servicing fee was agreed (though it was unclear whether it was ever paid) and, most important in the court's opinion, the hospital lost control over the receivables, and the funds, once those were deposited in a bank account. ${ }^{65}$ Thus, the court held that the SPV complied with the stringent standard of managing its own assets, despite the lack of substance and operational independence of the vehicle, which was the central aspect of the case (infra III.2). So far, it does not look a threatening environment for vehicle shielding.

This reduced risk has not prevented statutory reforms which have tried to shield securitization transfers from re-characterization, both at a federal ${ }^{66}$ and state level. ${ }^{67}$ The problem with this multiplicity of statutes is that they can create a cacophony of rules which hinders their usefulness as a complementary source to Article 9 in court decisions. The Endico court above resolved the issue pursuant to the reference to 'sale' contained in the federal Perishable Agricultural Commodities Act (PACA), despite Texas law containing an anti re-characterization provision which could have been deemed applicable. ${ }^{68}$ Thus, solutions on pure policy grounds, based on a simplification of the goods or evils of bankruptcy-remote transactions seem to be inadequate, no matter their sign. In this case, specific statutory rules that try to benefit an asset transfer for the sole reason of being made in the context of a securitization could obscure the clarity of the courts' process of logical construction. However, they seem unlikely to affect the outcome, which does not look problematic for bankruptcy-remote transfers.

(d) Among civil law countries Spain is an interesting example. ${ }^{69}$ The courts' approach has been quite formalistic in the past, in cases involving assignments (normally in the context of a factoring transaction): the recourse against the transferor was not considered

65 Re Doctors Hospital of Hyde Park, Inc, 2013 WL 5524696 (Bankr ND Ill 2013).

66 Attempts were made to introduce a safe-harbour rule in 1998 and in 2001 with the Bankruptcy Reform Act 2001. See Section 912 US Bankruptcy Reform Act; 107th Congress $\$ 912$ (2001); House of Representatives 333, which modified Section 541 of the Bankruptcy Act (which defines the bankruptcy estate) armour-plated the true-sale nature of transfers made in a 'securitization transaction' over 'eligible assets' to 'eligible entities'. Enron's demise, and the bad press of SPVs contributed to the reform's demise; and to proposals in the opposite sense, such as the Employee Abuse Prevention Act 2002, or Durbin-Delahunt Act, which, to protect workers' rights to salaries and pensions in case of bankruptcy of their employer, included a express provision on recharacterization of assignments as secured financing transactions (see Section 2798, 107th Congress (2002); and House of Representatives 5221, which introduced a new section 105 (e) in the Bankruptcy Act). This reform was also shelved, but the swing of reforms cautions against legislating on patrimonial matters in the heat of the political moment.

67 Reforms in Texas or Louisiana apply to 'every' sale of 'receivables', and prevent re-characterization absent any 'fraud or intentional misrepresentation'; and reforms in Delaware, Nevada, Alabama and other states apply to sales of receivables in securitization, and preclude re-characterization of 'any' sale of 'property' but only 'if done in the context of a securitization transaction. Other state statutes have a more narrow application to securitization of rights of utilities, typically in the energy sector. For a detailed analysis, see Kenneth Kettering, 'True Sale of Receivables: A Purposive Analysis' (2008) 16 Abi L Rev $519 f f$.

68 It is also unclear to what extent such state statutes would apply in the presence of federal bankruptcy law. Supposedly federal bankruptcy law must respect the property rights established under state law, as indicated by Butner $v$ United States, 440 US 48 (1979), but that depends on whether 'a federal interest requires a different result'; which could be the case if the court takes the view that the reorganization of a business is such interest. See Kettering (n 67) 557-58.

69 For further detail, see David Ramos Muñoz, 'Transacciones Trascendentes. Operaciones fuera de balance, disociación de la propiedad y problemas regulatorios, patrimoniales y de gobierno' (2012) 125 RDBB $201 \mathrm{ff}$. 
enough to re-characterize the transfer, ${ }^{70}$ but was an element in the few cases that applied a 'substance-over-form' test to find that an assignment was for the purposes of security. ${ }^{71}$ In those few cases, the courts' approach did not focus primarily on the economic effects, but on the contract language. ${ }^{72}$

Then, a statutory reform was passed in 1999 which provided bankruptcy protection to certain assignments made in the context of financial transactions (primarily factoring). ${ }^{73}$ Being sectoral rules, the new statutory provisions have not (or should not have) introduced new general principles applicable beyond the scope of the act. ${ }^{74}$ But they purportedly provide protection to the assignments that comply with statutory requirements. The new provisions, thus, give rise to a duality of approaches: one, generally applicable, where courts focus mostly on form (though they could potentially focus on substance, if it is very obvious) $;^{75}$ and another, specifically applicable to financial transactions, which primarily focuses on whether the assignee is a registered/regulated entity (and thus it is even more formal). ${ }^{76}$

Interestingly, the proliferation of specific statutory rules has given rise to another conundrum. Statutory rules for securitization (Royal Decree 926/1998) provided protection assignments done in a securitization 'provided that' there was 'no recourse' in the assignment. ${ }^{77}$ The above mentioned 1999 rules do not include the requirement of recourse to dispense protection, and while they were introduced in 1999 for some specific registered entities (with the purpose of applying to factoring) they were later expanded to encompass assignments done to registered securitization funds. ${ }^{78}$ This creates a problem

70 The Spanish Supreme Court in its Decision of 11 February 2003 (RJ 2003/938) held that the assumption by the transferor of the risk of insolvency is a disposable matter between the parties, and thus it does not affect the legal nature of the transaction, unless the assignment is done for the mere purposes of servicing. Thus, all assignments under a factoring contract have the effects of a property transfer over the receivables. See also Decision from 2 February 2001 (RJ 2001/1685). Scholars concur that even assignments pro solvendo (ie with recourse) have the effect of payment, not of security. See Antonio Ortí Vallejo, 'Cesión de créditos futuros y factoring' (InDret, Octubre 2010) 11; Fernando Pantaleón Prieto, 'Cesión de créditos' (ADC 1988) 1053; Javier García de Enterría, 'Contrato de factoring y cesión de créditos' (Civitas, 1995) 132. Nevertheless, the Decision of 4 December 2007 (RJ $2007 /$ 8897) associated disparate factors, such as the recourse, servicing and pro solvendo assignment with the absence of a transfer of property.

71 Decisions of 2 February 2001 (RJ 2001/1685) and 4 December 2007 (RJ 2007/8897).

72 References to language such as 'we have transferred' were taken to justify sale effects (Supreme Court Decision of 11 February 2003 (RJ 2003/938); and of assignment 'salvo buen fin', to justify the absence of a true sale (Supreme Court Decision of 27 June 2003 (RJ 2003/4313).

73 Additional Provision $3^{\mathrm{a}}$ of the Act 1/1999, 5 January, about Venture Capital Entities, with the purpose of protecting certain assignments of receivables done in the framework of factoring against the assignor's insolvency.

74 This incidentally poses another problem of statutory construction: the 1999 reform was justified as a reaction to the harsh bankruptcy regime of 'retroaction' (ie the possibility to undo every transaction undertaken between the moment when the court considered that the entity was insolvent, and the moment when insolvency was actually declared). Now that the regime was eliminated in 2003 it is unclear why the privilege should continue. See José Ramón García Vicente, 'La Prenda de Créditos' (Civitas, 2006) 181.

75 See the Supreme Court Decision of 5 March 2004 (RJ 2004/1811), where the Court examines the substance of the agreement to decide to whom corresponds the ownership over the receivables and thus the right to the surplus.

76 Such seems to be the construction by the courts. See Supreme Court Decisions of 28 May and 6 October 2004 (RJ 2004/3553, 2004/5986). See also the decision of 11 February 2003 (RJ 2003/938).

77 Art 2.2.b. of Royal Decree 926/1998 requires that that: (1) the assignment is full and unconditional, for the rest of the remaining term until maturity; and that (2) the assignor does not grant the assignee any warranty, or guarantees the good completion (buen fin) of the transaction.

78 The original provision for financial assignments required the assignee be a credit institution, before being extended to include securitization funds. See No 2 of Additional Provision $3^{\mathrm{a}}$ of Act 1/1999, which also requires that the assignor be a business, and the 
of legal construction: should one conclude that the 1999 Act derogates the requirement included in the 1998 decree, pursuant to the principles of lex superior derogat inferior (Royal Decree $v$ Act of Parliament) and lex posterior derogat priori (1998 v 1999 provisions); or that the requirements of the 1998 Act and 1998 Decree apply cumulatively, pursuant to the principle of lex specialis derogat generalis (one covers a broader range of financial assignments, the other only securitization). ${ }^{79}$ Yet another example of how statutory reform, when it considers sectoral, rather than overall policy, muddles the picture, rather than enhancing clarity and certainty.

Another reason why such reforms can be criticized is that it is unclear why they were passed in the first place: there is scant evidence of cases where courts decided to recharacterize an asset transfer, all involving overwhelming factors in favour of such recharacterization, and none involving a securitization, or a similar bankruptcy-remote transaction.

\section{Threats to the separation between sponsor and vehicle: substantive consolidation}

If re-characterization is a recurrent concern for transaction parties, 'consolidation' is those parties' worst nightmare: even if the transfer was properly done, a court could, in theory, merge the estates of transferor and transferee, and erase the benefits of partitioning in a single stroke. But is such risk a clear and present one for bankruptcyremote transactions?

The answer seems to be 'no'. First, it is important to draw a distinction. Unlike accounting consolidation, 'substantive consolidation' is no routine matter. Accounting rules merely require 'control' of the entity to effect consolidation, and, no matter the controversy about the definition of this concept in relation to SPVs in the wake of the Enron scandal, ${ }^{80}$ accounting consolidation only affects the way the group accounts are presented. Consolidation under corporate/bankruptcy law is a much more drastic measure: those rules rely on legal personality; which, to be sidestepped, needs exceptional circumstances to be present. Thus, no matter how dependent a bankruptcy-remote SPV

receivables come from its business activity, and exist at the time of the conclusion of the assignment contract, or arise during the next year from the assignor's activity, or the assignment contract includes the identity of the future debtors; that the assignee pays the amount of the receivables with a deduction of the cost of the services rendered, and that, in case the parties agree on the nonexistence of recourse, the assignee has satisfied the assignor, in all or part, the amount of the assigned receivable before its maturity. 79 See Muñoz (n 69) 207.

80 Interpretation SIC-12, of IASB established that, for the purpose of determining dependence of an SPE regard should be had not so much to things like voting rights, board control, etc, but, rather, to what party bore the risks and got the rewards of the vehicle's activity. See SIC Interpretation 12 Consolidation Special Purpose Entities, 1999, paras 1, and 10 (c) and (d). The issue acquired momentum after the Enron scandal unveiled the potential for abuse of SPEs. See Power's Report, 39-234. New accounting rules were passed in the USA, again enshrining the new 'risk-and-rewards' approach. See Interpretation 46 (R) Consolidation of Variable Interest Entities 2003. However, those rules included an exception for Qualified Special Purpose Entities (QSPEs), a category conceived primarily for securitization transactions. Then, the financial crisis made clear that credit institutions had underreported risk and economic dependence of their vehicles by making use of the loopholes created by the primarily 'bright-line' approach of the rules. See Muñoz (n 1) 317-18, 321-23. Reforms were introduced by the IASB, to switch back to the criterion of 'control', giving up the aim to consolidate SPEs. See IASB ED 10 Consolidated Financial Statements para 10 (focuses on 'control' as 'power to direct' the activities of the consolidated entity, ie in a more traditional sense). In exchange there seems to be a greater emphasis on disclosure of non-consolidated positions. See IASB 10 Consolidated Financial Statements and IFRS 12 Disclosure of Interests in Other Entities Effect analysis September 2011 (updated January 2012) 5, 25-26. 
may be to its sponsor, this does not suffice to ignore the partitioning between the assets of the two.

In second place, 'substantive consolidation', as a concept, is only known in the USA; ${ }^{81}$ where it evolved separately from veil piercing in the 1940s, as a manifestation of the broad equity powers given to the bankruptcy court, ${ }^{82}$ to deal with cases where insolvent (or near-insolvent) debtors transferred assets to subsidiaries to keep them bankruptcyproof. $^{83}$

Given its origins in equity, deeply intertwined with the discretionary exercise of powers by chancery courts, a clear formulation of the doctrine is elusive. Attempts to systematize it show its similarities to veil piercing; ${ }^{84}$ except that substantive consolidation makes a lesser emphasis on 'fraud', and requires a more 'utilitarian' weighing of pros and cons. In any event, it is a last resort remedy for cases where the estates of the entities are too entangled (internal confusion), or creditors deal with the entities as a single economic unit, and do not rely on the separate personality of each of them (external confusion). ${ }^{85}$ In those cases, consolidation may be needed to protect creditors' legitimate expectations, ${ }^{86}$ or prevent the illegitimate extraction of assets. ${ }^{87}$

Such confusion and commingling, however, is unlikely to arise in bankruptcy-remote transactions. SPVs are often not subsidiaries of the sponsor (a constant element in substantive consolidation cases) and typically comply with so-called 'separateness covenants' elaborated by rating agencies: respect of formalities, conducting business in their own name, paying debts out of their own funds, keeping separate books, records and accounts, restricting relationships with the sponsor and associated entities..., ${ }^{88}$ which prevent internal commingling.

81 Peter J Lahny IV, 'Asset Securitization: A Discussion of the Traditional Bankruptcy Attacks and an Analysis of the Next Potential Attack, Substantive Consolidation' (2001) 9 Am Bankr Inst L Rev 815; Michael J Cohn, 'Asset Securitization: How Remote Is Bankruptcy Remote?' (1998) 26 Hofstra L Rev 929; Maria Elizabeth Kors, 'Altered Egos: Deciphering Substantive Consolidation' (1998) 59 U Pitt L Rev 381.

82 Kors (n 81) 397.

83 At the beginning the 'turnover' doctrine, which invalidated the transfer, was sufficient, but when subsidiaries had creditors of their own a further step was needed, ie consolidating the estates of all entities. Such consolidation happened in Sampsell $v$ Imperial Paper \& Color Sampsell v Imperial Paper \& Color, 313 US 215 (1941), though the arguments were closer to the doctrine of fraudulent transfers. In Stone v Eacho (Re Tip Top Tailors, Inc), 127 F2d 284 (4th Cir 1942), the framing of the doctrine was closer to its current 'alter ego' approach. See Kors (n 81) 393.

84 Re Vecco Construction Industries, Inc, 4 BR 407, 410 (Bankr ED Va 1980), the court referred to a checklist of seven elements: (1) degree of difficulty in segregating and ascertaining individual assets and liability; (2) presence or absence of consolidated financial statements; (3) profitability of consolidation at a single physical location; (4) commingling of assets and business functions; (5) unity of interests and ownership between various corporate entities; (6) existence of parent and intercorporate guarantees on loans; (7) transfer of assets without formal observance of corporate formalities. See also the thorough study of other checklists in Kors (n 81) $400-2$.

85 Alexander v Compton (Re Bonham), 229 F3d 750 (9th Cir 2000); Union Sav Bank v Augie/Restivo Baking Co Ltd (Re Augiel Restivo Baking Co), 860 F2d 515, 518 (2d Cir 1998).

86 Re Mortgage Investment Co, 111 BR 604, 610 (Bankr WD Tex 1990). See also Muñoz (n 1) 89.

87 In such cases, however, a less invasive remedy such as the setting aside of the transaction by means of the law of fraudulent transfers should be preferred. See Kors (n 81) 420.

88 Standard \& Poors Structured Finance Auto Loan Criteria Standard\&Poors, 47-48. Covenants also include restrictions to engage in activities other than owning and operating the assets transferred; and to not acquire other assets or are subject to other liabilities than those associated with the specific task for which they are created (that includes not guaranteeing the debt of other entities, as well as not engaging in mergers or divisions). See Moody's Investor Services, Auto-Loan Criteria, pp. 47-48; Forrest Pearce, 'Bankruptcy Remote Special Purpose Entities and a Business' Right to Waive its ability to File for Bankruptcy' (2012) 28 Emory 
On an external level, the whole marketing of bankruptcy-remote products is based on the market's perception that there is a separation between the risks of the sponsor and the risks of the vehicle: it would make little sense to market the product as another type of personal debt of the sponsor/originator.

Therefore, the only risk would be if the transaction is mishandled, or the courts rely on a pure 'policy' approach to consolidation. Evidence in the USA suggests the opposite. In the few cases where the possibility of consolidation was floated the courts were against the idea. ${ }^{89}$ In $R e$ CEIDCO, several debtors filed for bankruptcy and requested substantive consolidation to strengthen their bargaining position against the secured creditor (Lehman Brothers) who opposed the move. The court refused to grant the request in the absence of creditors' approval $;{ }^{90}$ and held, in line with the above explanation, that both debtor and creditor had structured the transaction relying on the entities' separateness. As to the policy argument, the court held that:

Debtors infer that the corporate structure insisted upon by Lehman somehow amounts to an attempt to create a 'bankruptcy remote' entity, an evil they would cure by substantive consolidation. Their theory is unavailing. First, even if one or more Debtors or their affiliates is 'bankruptcy remote' or at least 'U.S. bankruptcy remote' Debtors have cited no law that would be violated by such a corporate structure ... Second, substantive consolidation is one of 'the bankruptcy court's general equitable powers ...' .... and it would not be equitable for this court to ignore the prepetition wishes of Lehman and the Debtors by disregarding the corporate structure the parties so carefully created by agreement. The fact that other unsecured creditors may lose their ability to be paid is neither equitable nor inequitable. It is the natural consequence of what might happen if Lehman successfully pursues the remedies set forth in Debtors' dire predictions. ${ }^{91}$

The issue was most thoroughly examined in the Doctors Hospital case, a case where other issues, such as the existence of a fraudulent transfer, or the re-characterization of the transfer ('Threats to the asset transfer: avoidance and re-characterization' section) were present, but whose central issue was whether the securitization vehicle (MMA Funding, LLC) had separate 'real existence'.

The transaction was quite complex. The originator of the receivables (Medicare and Medicaid reimbursements, as well as payments from private insurance companies) was Doctors' Hospital, whose owner, Desnick, also owned HPCH, the entity that owned the land where the hospital was situated, which it leased to the hospital. The need for extra funding prompted the request of a loan from Daiwa (the Daiwa loan). For structuring purposes, MMA Funding LLC, a special purpose vehicle, was set up: under a 'true

Bankr Dev J 522; David B Stratton, 'Special-Purpose Entities and Authority To File Bankruptcy' (2004) Am Bankr Inst J 36; Michael T Madison, The Law of Real Estate Financing (2009) § 13:38, at 13-70.

89 See Re Central European Industrial Development Company (CEIDCO) LLC d/b/a Ceidco, 288 BR572 (Bankr ND Calif, 2003); Re General Growth Properties 409 BR 43, (Bankr SDNY 2009); Bank of NY Trust Co v Official Unsecured Creditors Comm (Re Pac Lumber Co), 584 F3d 229 (5th Cir 2009).

90 In this regard, the court relied on Bruce Energy Centre Ltd v Orfa Corp of America (Re Orfa Corp of Philadelphia), 129 BR 404 (Bankr ED Pa 1991), which represents a restrictive approach to substantive consolidation, by requiring the affirmative vote of each class of creditors.

91 Re Central European Industrial Development Company (CEIDCO) LLC d/b/a Ceidco, 288 BR572 (Bankr ND Calif, 2003) at 576. 
contribution' (ie not 'true sale') scheme Doctors' Hospital transferred the receivables to the vehicle; in exchange, the vehicle would transfer equity, and make 'distributions' to Doctors' Hospital. The receivables would then be transferred from the vehicle to Daiwa, and Daiwa would transfer the loan advances to the vehicle. A later loan was instrumented from Nomura to HPCH (the loan was then securitized by Nomura, which transferred it to an SPV, which transferred it to a trust managed by Lasalle (which explains Lasalle's involvement in the proceedings).

Graphically:

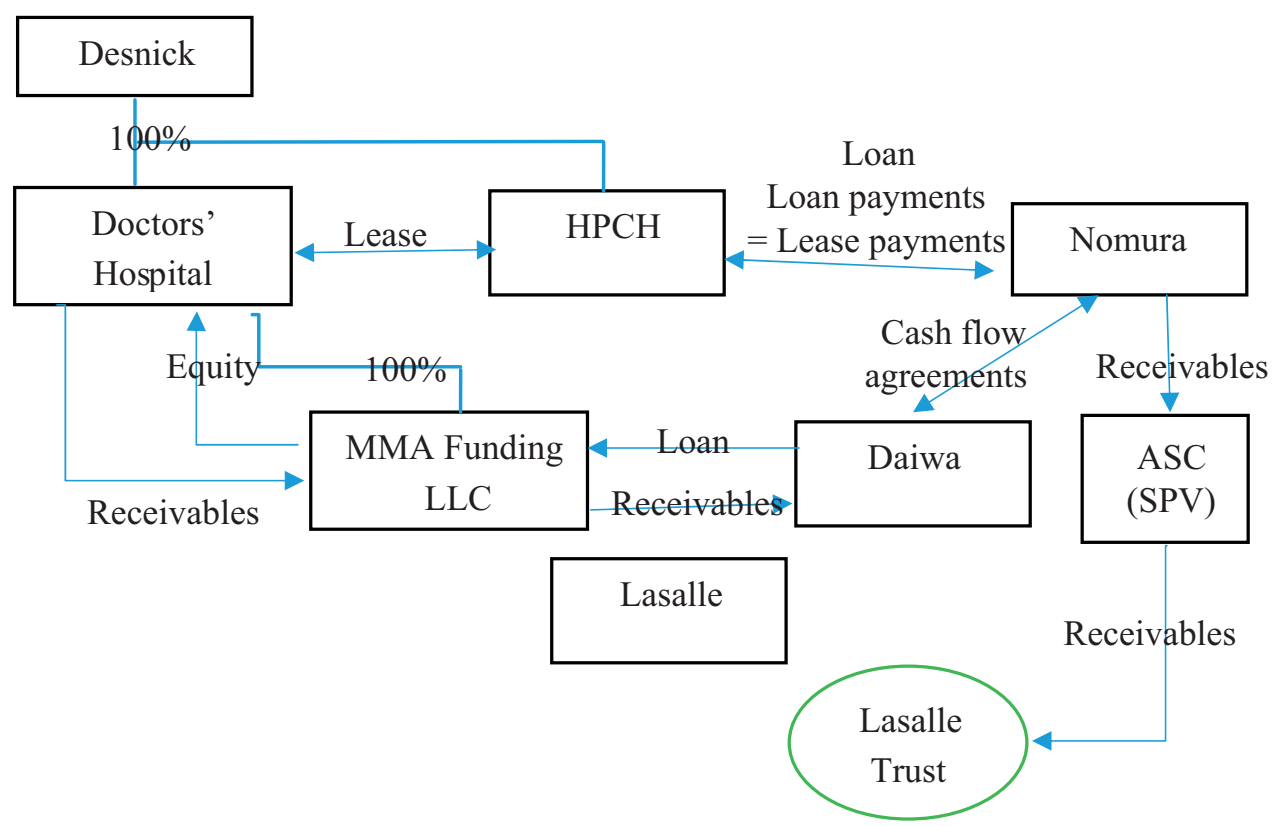

The complexity of the deal required the 'cash flow agreements' (consisting, among others things, in an intercreditor agreement, and a cash collateral agreement) to organize the Daiwa-MMA-Doctors'-HPCH-Nomura-Lasalle back-and-forth cash flows. ${ }^{92}$ The important things were that the Nomura loan would be paid out of the funds from the Daiwa loan, and that Desnick (through Doctors' Hospital) fully controlled the securitization vehicle. Thus, when Doctors' Hospital went bankrupt, the trustee sought to recover the receivables transferred to Daiwa, alleging that the transfer was fraudulent. Since the receivables were, technically, property of MMA Funding (the vehicle) when transferred, the trustee sought to establish that MMA Funding had no separate legal existence, and the receivables had always been the property of Doctors' Hospital. The bankruptcy court decided in 2007 that the receivables belonged to the SPV, which had

92 The case involved some additional complexities, related to the property structure of MMA Funding, or the administration of the securitization by Nomura of its loans, which have been omitted here because they do not affect the legal issues. For further detail on the structure, as well as the cash flows, see Muñoz (n 1) 192-93. 
separate existence, ${ }^{93}$ and this finding was confirmed by the district court. ${ }^{94}$ The Court of Appeals for the Seventh District, however, remanded the case for further analysis, because it had not been shown to its satisfaction that MMA Funding enjoyed a 'valid existence' as a 'legitimate bankruptcy remote vehicle', because, in this particular case:

MMA Funding lacked the usual attributes of a bankruptcy remote vehicle. It was not independent of Desnick or the Hospital; ... and MMA Funding operated as if it were a department of the Hospital. It did not have an office, a phone number, a checking account, or stationery; all of its letters were written on the Hospital's stationery. It did not prepare financial statements or file tax returns. It did not purchase the receivables for any price (at least, if it did, the record does not show what that price was). Instead of buying the receivables at the outset, MMA Funding took a small cut of the proceeds every month to cover its (tiny) costs of operation. ... The Hospital continued to carry the accounts receivable on its own books, as a corporate asset ... There is scarcely any evidence in this record that MMA Funding even existed, except as a name that Daiwa's and Desnick's lawyers put in some documents. ${ }^{95}$

What should matter in that decision is not the Court of Appeals' willingness to disregard the vehicle's separate personality (the case was remanded to the bankruptcy court for a final decision), but the 'reasons' for doing so. The court had no problem with 'bankruptcy remote vehicles' as a category, in fact, it treated them as a sort of 'market standard' to be used as a yardstick for the vehicle's legitimacy. The court was worried about the lack of independence and separateness of the vehicle in 'this particular case', which it found odd, according to the court's understanding of how bankruptcy-remote vehicles worked. Thus, the question was never whether the intrinsic characteristics of an SPV can jeopardize a vehicle's shielding, but what does a 'normal' bankruptcy remote SPV look like, so that deviant structures can be identified, and disregarded.

The bankruptcy court analysed this issue thoroughly, to conclude that the vehicle had separate 'real' existence. Despite the fact that the test required by the Court of Appeals was more stringent (as it required the vehicle to 'buy assets' and 'manage assets', 'in its own interest rather than the debtor's') the Bankruptcy Court held that the vehicle complied with it. ${ }^{96}$ The court used precedent and expert sources to conclude that elements such as the lack of an address or stationery were less important than the lack of segregated accounts to establish a separate existence, and that the vehicle in this case was 'normal' pursuant to market standards (it was 'normal' to receive consideration for the

93 Re Doctors Hospital of Hyde Park, Inc, 360 BR 787 (Bankr ND Ill 2007).

94 Paloian $v$ LaSalle, 406 FSupp2d 299 (ND Ill 2007).

95 Paloian $v$ LaSalle, 619 F3d 688, 696 (2010).

96 Re Doctors Hospital of Hyde Park, Inc, 2013 WL 5524696 (Bankr ND Ill. 2013). The court also held, however, that the remand opinion by the Court of Appeals was not calling for substantive consolidation, because it had made no references to substantive consolidation decisions, but, rather, relied on United Airlines, Inc v HSBC Bank USA, NA et al, 416 F3d 609, 611-12 (7th Cir 2005) to establish its 'substance-over-form' test, a decision where the issue at stake was the re-classification of a lease as a sale or a secured loan (less drastic than substantive consolidation). Then, the court went on to argue why the transfer there of receivables should neither be held void (as there had been no fraudulent transfer) nor re-characterized as a secured transaction ('Threats to the asset transfer: avoidance and re-characterization' section). The complexity of the facts adds confusion to the analysis. It is true that the allegations about the vehicle's lack of separate existence were not made to request substantive consolidation, but were only instrumental to a finding that the receivables were the property of their originator, and had been fraudulently transferred. However, since the consequence, in terms of ownership, would have been the same as in a substantive consolidation case, it should have made sense to apply the same standard. It is, however, unclear whether this was what the Court of Appeals wanted, or whether the Bankruptcy Court interpreted the mandate correctly. 
receivables in the form of subordinated notes). It also held that the vehicle respected corporate formalities, kept separate records and had separate operations. ${ }^{97}$

For legal purposes, the most important holdings of the court were two-fold. First, the court held that it was difficult to apply precedents on a 'substance-over-form' analysis, because bankruptcy remote structures have 'no purpose and no substantial effect' beyond excluding bankruptcy law, and 'it can hardly be argued that all secured loans are subject to attack for that reason'. ${ }^{98}$ Thus, to determine whether the MMA Funding was a 'legitimate' bankruptcy-remote vehicle regard had to be had to 'the limited, special purpose function of the entity must be evaluated', because 'it was not making widgets'. ${ }^{99}$ Second, it was important that the bank relied on MMA Funding's status as a bankruptcyremote entity when making the loan, and this was important because 'There is good reason to avoid judicial disruption of commercial transactions based on a balancing of factors susceptible to subjective interpretation'. ${ }^{100}$ This short statement constitutes the closest there is to a 'policy position' vis-à-vis vehicle shielding: caution before upsetting market practice for policy reasons with no clear limits.

Outside the USA, the probability of consolidation is slighter still: 'substantive consolidation' does not exist as a separate remedy subject to broad equitable powers; only 'reverse' veil piercing could be used, and is quite unknown. ${ }^{101}$ Even if it were as exceptional as veil piercing (and not more), veil piercing is applicable only in exceptional circumstances, normally involving creditor fraud ${ }^{102}$ or confusion. ${ }^{103}$ In securitization, unless the sponsor/originator regularly takes assets from the pool, to replace them later, ${ }^{104}$ it is very unlikely that courts will intervene, and intervention on policy grounds (ie absent actual confusion of estates) is almost unheard of.

A good example of the courts' reluctance to unravel complex financial deals only because they involve SPVs can be found in the English case of Re Polly Peck. ${ }^{105}$ The action in that case was one of veil piercing, not substantive consolidation, and was pursued by investors in the securities issued by the vehicle, not creditors of the sponsor, ie in a

\footnotetext{
97 Re Doctors Hospital of Hyde Park, Inc, 2013 WL 5524696 (Bankr ND Ill 2013) 220-25.

98 ibid 202.

99 ibid 226.

100 ibid 232.

101 Karen Vandeckerckhove, Piercing the Corporate Veil (Kluwer Law International 2007) 405, 452, 474, 498, reaching the conclusion that substantive consolidation, understood as the pooling of the estate of the subsidiary with that of the parent is even more exceptional than veil piercing in Belgium, equally exceptional in France, excluded in Germany, and extremely rare in Britain. Only in France does there seem to be the possibility of 'extension' of bankruptcy to subsidiaries, subject to broad powers, in a way similar to the USA, but it is unclear how far those powers can go beyond 'procedural' consolidation, and to substantive consolidation.

102 See, for example, the recent Spanish Supreme Court decision of 3 January 2013 RJ 2013\1628 where the Supreme Court consolidated the patrimonies of several subsidiaries with that of the parent company after having concluded that the whole purpose of the successive restructurings was to siphon out assets from the parent.

103 Vandeckerckhove (n 101) 380-527.

104 It is important to note that, whereas such instances are not common, nor are they unheard of, as illustrated in the saga of New Century Financial. See Re National Century Financial Enterprises, Inc, 2006 WL 2849784 (SDOhio 2006). In the case at hand, however, there was no claim of substantive consolidation by New Century's creditors (sine those had already benefited from the appropriation of funds by New Century). Rather, it was securitization investors who sued New Century, but, to do so, they did not resort to veil piercing, but to a securities fraud action.
}

105 Re Polly Peck International plc (In Administration) (No 4) [1996] 2 All ER 433, [1996] BCC 486. 
manner of speaking, the action moved 'upwards', and not 'downwards'. However, the analysis serves well for substantive consolidation. The court flatly dismissed all allegations of veil piercing pursuant to all the different theories used by the plaintiffs (agency, cipher, façade or alter ego). It held, in particular, that the fact that the different entities acted as a single economic unit could not result in veil piercing. The implication is that the court did not see the 'instrumentality' of the vehicle for the group purposes as something that justifies the disregard of legal personality. In the court's own words, 'substance means legal substance, not economic substance (if different)', and, furthermore, 'the separate legal existence of group companies is particularly important when creditors become involved'. ${ }^{106}$

These decisions confirm the worries of those who argue that the market's acceptance of bankruptcy-remote structures has rendered them 'too-big-to-fail' in the eyes of the law; and the validation of market practice has become a fundamental reason to uphold the

legal tenets that give rise to vehicle shielding. ${ }^{107}$ But from this conclusion one should not imply, conversely, that bankruptcy-remote transactions are per se a threat to basic principles of bankruptcy law. Perhaps courts should be more willing to inquire, and less inclined to accept what market practice gives them at face value, perhaps the word 'bankruptcy remote' should not be a sort of shibboleth that gives the transaction a free pass, but nor should the instrumentality of the SPV, the narrowing of its activities, and its dependence of the sponsor be elements considered with suspicion, because they are essential to fulfil the transaction's purpose of securing a debt, and all parties involved (including the sponsor and its creditors) relied upon them. As paradoxical as it may sound, the best way to confront these new structures in the field of substantive consolidation is by applying old principles, which rely on confusion, commingling and the external reliance of the entities as a single unit, for fraudulent purposes.

\section{Threats to vehicle shielding in practice}

The previous sub-section analysed the threats to vehicle shielding traditionally considered relevant, and concluded that concerns may have been overstated. If there is a 'policy' stance, it is favourable to bankruptcy-remote transactions. This does not mean that the whole argument about partitioning versus consolidation is entirely pointless. The tension resurfaces in situations where, given the particularities of the case, the solution will not be seen as having broader implications beyond the specific facts. This happens both in 'traditional' transactions, such as 'cash securitizations' when courts can rely on specific circumstances, and, in more advanced transactions, such as securitizations of future assets, whole business or synthetic transactions, where the connection between policy argument and facts is present, but, due to the complexity of the transaction, it is less obvious.

106 ibid 498.

107 Kettering (n 27). 


\section{Threats to vehicle shielding in cash securitizations}

Unlike the cases analysed in previous sections, in situations where their decision was less susceptible to having precedential value, or drastic effects, courts (mainly in the USA) have been more willing to look for imaginative ways to find exceptions to vehicle shielding without calling them by that name.

In the context of asset transfers, for example, courts have shown their willingness to consider policy arguments to disregard property rights for the purpose of granting 'temporary possession/control' rights. In In re LTV Steel, ${ }^{108}$ LTV had set up two subsidiaries to securitize its rights over accounts receivable and inventory. However, when it filed for bankruptcy, it received permission by an interim order to use the proceeds from those receivables to continue its activity. The motion of one of the subsidiaries' creditors (Abbey National Treasury service plc) to modify the interim order was overruled. On the question of whether the receivables were part of the debtor's estate (and thereby whether the court had jurisdiction over them) the court held that this issue could not be decided in the context of an interim order, as it required an evidentiary hearing, but it added that (1) the debtor had an 'equitable' interest in the property, which provided a sufficient basis for the interim order, because: 'To suggest that Debtor lacks some ownership interest in products that it creates with its own labor, as well as the proceeds to be derived from that labor, is difficult to accept'; and that (2) 'granting Abbey National relief from the interim cash collateral order would be highly inequitable', considering the consequences for employees and retirees. ${ }^{109}$

Being an interim order, where full knowledge of the facts is less important than a proper balancing of equities and hardships, the decision lacks precedential value; but it illustrates how an excessive focus on the absolutes of re-characterization can miss the importance of the smaller details, such as the temporary right to use the assets. The court did not focus on substance or form, economic aspects or parties' intention: it found a minimum basis for a right, and did an analysis based on broad policy considerations applied to the equities of the case.

A similar contrast between a reluctance to make decisions with permanent effect and precedential value, and the boldness to adopt a more policy-reliant approach when the decision can be confined to the facts of the case, and has temporary effects, can be seen in the context of the so-called 'indirect' or de facto consolidation. In such cases, bankruptcyremote SPVs enter bankruptcy at the same time their sponsor does; and, while they

108 Re LTV Steel Company Inc, 274 BR 278 (BkrtcyNDOhio 2002).

109 The court elaborated on its reference to the equities of the case, by holding that: 'The Court is satisfied that the entry of the interim order was necessary to enable Debtor to keep its doors open and continue to meet its obligations to its employees, retirees, customers and creditors. Allowing Abbey National to modify the order would allow Abbey National to enforce its state law rights as a secured lender to look to the collateral in satisfaction of this debt. This circumstance would put an immediate end to Debtor's business, would put thousands of people out of work, would deprive 100,000 retirees of needed medical benefits, and would have more far reaching economic effects on the geographic areas where Debtor does business. However, maintaining the current status quo permits Debtor to remain in business while it searches for substitute financing, and adequately protects and preserves Abbey National's rights. The equities of this situation highly favour Debtor.' Re LTV Steel Company Inc, 274 BR 278 (BkrtcyNDOhio 2002) at 286. 
formally keep a separate estate, the sponsor uses the entities' collateral to prop up its own business. $^{110}$

This was an issue in re General Growth Properties. ${ }^{111}$ In that case, the court denied the motions of several secured creditors to dismiss the bankruptcy filing by several SPVs. One of the creditors' arguments was that, by filing for bankruptcy, the debtor SPVs were acting to the detriment of secured debtors, and to the benefit of the sponsor (and parent) company; which benefited from the automatic stay, by using the cash that would otherwise have been destined to satisfy the principal payments of the loans subscribed by the SPVs to pay for its reorganization.

The court stated that since the bankruptcy of each SPV would be kept separate, there was no risk of substantive consolidation; and while acknowledging that the bankruptcy filing had caused 'inconvenience' to secured creditors, directors were entitled to, in fact, they 'should' take into consideration the 'interest of the group' in deciding whether to file for bankruptcy; and that this was an issue entirely separate from substantive consolidation. $^{112}$

Again, broader policy considerations can miss tinier details. In re General Growth Properties, the SPV's property rights over the assets was not even disputed, and the consolidation of patrimonies not even suggested: the whole issue was interim control (and right of use) over the assets. Thus, under American law at least, control, or possession, over the assets can trump ownership in the short-term, and transform a property right in a guarantee of 'adequate protection', which relies on the court's criterion about the revenue-generating capacity of the use of the assets of the bankrupt firm. ${ }^{113}$

This rearrangement of the terms of the debate can render substantive consolidation moot. In many cases, what matters is whether a certain measure implies de facto consolidation in the short term. In re Pacific Lumber, ${ }^{114}$ the issue was the procedural (not substantive) consolidation and joint administration of the bankruptcy of six affiliated entities in the redwood timber business in California. Principal debtors were Palco, the operating company (which operated a sawmill, power plant and the town of Scotia, California) and Scopac, a Delaware SPV, wholly-owned by Palco, to which it had transferred ownership of timberland (the 'Timberlands') and which sold \$867.2 million

110 Pearce (n 88) 514; Jason Lynch, 'Reevaluating Bankruptcy Remoteness: Transfers of Risk, Implications of the GGP Reorganization' (2010) Am Bankr Inst J 58.

111 Re General Growth Properties 409 BR 43, (Bankr SDNY 2009).

112 ibid 70.

113 The court stated that 'we find Abbey National's contention that its collateral is being consumed at a rate of Ten Million Dollars $(\$ 10,000,000.00)$ per day to be disingenuous. It is true that the pre-petition receivables are being used by Debtor to purchase and manufacture more steel. However, Debtor's use of the pre-petition receivables will inevitably lead to an increase in the value of post-petition receivables and inventory, in which Abbey National has a security interest. This conclusion is amply supported by the affidavit of John T. Delmore, Debtor's Assistant Controller. Mr. Delmore's affidavit indicates that as of January 15,2001 , there was a sufficient equity cushion in both post-petition inventory and receivables to provide adequate protection to all of Debtor's secured lenders. The amount of the respective equity cushions equalled $39 \%$ for the receivables lenders and $179 \%$ for the inventory lenders. Furthermore, it appears that Debtor's business will continue to generate additional post-petition receivables and inventory sufficient to protect Abbey National's interest in the near future'. Re LTV Steel Company Inc, 274 BR 278 (BkrtcyNDOhio 2002) at 286-87.

114 Bank of NY Trust Co v Official Unsecured Creditors Comm (Re Pac Lumber Co), 584 F3d 229 (5th Cir 2009). 
in notes secured by those assets: despite having separate corporate structures they were an integrated company. ${ }^{115}$

Two competing reorganization plans were presented to the court: one presented by Bank of New York, which was the Indenture Trustee (which was rejected) and one presented jointly by a creditor (Marathon) and a competitor (MRC) of Palco, which was accepted, and entailed joint ownership by both creditor and competitor (though MRC would manage the business). To achieve that result, it proposed 'to dissolve all six entities, cancel intercompany debts, and create two new entities, Townco and Newco. Almost all of Palco's assets, including the town of Scotia, California, would be transferred to Townco. The Timberlands and assets of the sawmill would be placed in Newco, ${ }^{116}$ with a contribution by MRC and Marathon to pay claims against the SPV, Scopac.

The trustee appealed the court's confirmation of the plan, arguing, among other things, that it gave effect to a de facto substantive consolidation. The court labelled substantive consolidation an 'extreme and unusual remedy', 117 and acknowledged the concerns about it, 'especially in a case involving securitized lending through a bankruptcy-remote special purpose entity like Scopac'; ${ }^{118}$ but quickly dismissed the allegation, holding that it had not been proven in the case. ${ }^{119}$ This shows that the absolute legal protection of 'separate legal personality' is difficult to implement in practice in cases where the SPV is completely dependent on the sponsor/originator for the servicing and collection of the receivables, and for operating the business that generates those receivables; while the sponsor/originator depends on the SPV's assets as collateral: ${ }^{120}$ in such cases, the rights of the vehicle's creditors may be preserved by the same protective standards given to secured creditors, such as the 'absolute priority' rule, or the 'fair and equitable' standard, ${ }^{121}$ and the separate personality of the vehicle can have a limited effect in such a reorganization context. ${ }^{122}$

115 'One of Scopac's three directors sat on Palco's board, and the companies had the same CEO, CFO, and General Counsel for substantially all of the relevant period. Palco had the sole right to harvest Scopac's timber, which Palco then processed and sold. Scopac was to repay the Noteholders with proceeds from its sales to Palco.' See Bank of NY Trust Co v Official Unsecured Creditors Comm (Re Pac Lumber Co), 584 F3d 229 (5th Cir 2009) at 238.

116 ibid.

117 ibid 250. In so doing it referred to Re Gandy, 299 F3d 489, 499 (5th Cir 2002).

118 In a footnote the court elaborated further on substantive consolidation's impact on investors' confidence in the value of the collateral. Thus, 'if courts were 'not wary' of its use, 'the practice of securitization, a powerful engine for generating capital, will become less useful; and the cost of capital will increase'. See Bank of NY Trust Co v Official Unsecured Creditors Comm (Re Pac Lumber Co), 584 F3d 229 (5th Cir 2009) at 251.

119 'allegations that unsecured Palco claims were paid with Scopac assets subject to its lien have been addressed and rejected above. Its only other evidence of substantive consolidation is based on the erroneous contention that the plan commingled intercompany administrative claims.' Bank of NY Trust Co v Official Unsecured Creditors Comm (Re Pac Lumber Co), 584 F3d 229 (5th Cir 2009) at 250-51.

120 In this case, Palco (the operating company) needed Scopac to gain access to secured funding, and Scopac needed Palco to exploit the assets of its property (in this case the need was more acute because the exploitation of the Timberlands required a licence), but this is not unlike a securitization of financial assets where the specialized nature of the business (or even the requirement of a licence to originate, or trade on, certain assets) links the assets to the person of the servicer, and makes the 'formal' property transfer much easier than the actual replacement of the party supposedly rendering a service.

121 See John D Ayer, 'Rethinking Absolute Priority after Ahlers' (1989) 87 Mich L Rev 963; Elizabeth Warren, 'A Theory of Absolute Priority' (1991) 9 Ann Surv Am L 9; James White, 'Absolute Priority and New Rule' (1991) 8 TM Cooley L Rev 1; Ralph Adam, 'Fine Unjamming the Cram Down' (1978) 52 Am Bankr LJ 321-39; Kenneth Klee, 'Cram Down II' (1990) 64 Am Bank LJ 229.

122 In this case, the plan was adopted against the will of most secured creditors (a cram-down plan) and the main discussion focused on whether the valuation of the noteholders' collateral was adequate; and whether the 'fair and equitable' standard required 
The boundaries of separation of patrimonies can be permeated in even more imaginative ways. The case of Bank of New York $v$ FDIC ${ }^{123}$ (NextBank I) arose out of the securitization of credit card receivables by NextBank NA, which used a trust SPV/SPE, and several interrelated transaction documents: a Trust Agreement, an Administration Agreement, a Transfer and Servicing Agreement and a Master Indenture. NextBank was transferor and servicer; and, when it entered receivership, the Federal Deposit Insurance Corporation (FDIC) was appointed receiver. This appointment should have activated an acceleration clause in the Master Indenture. ${ }^{124}$ However, the FDIC refused to honour that clause; and kept the transaction going, using noteholders' capital to purchase new credit card receivables, and paying interest pursuant to the non-accelerated schedule. ${ }^{125} \mathrm{BNY}$, as trustee sued the FDIC for conversion.

The lawfulness of the FDIC's action depended on whether NextBank had 'entered into' the Master Indenture agreement, pursuant to the language of Section 1821 (e) (12) (A) of the Financial Institutions Reform Recovery and Enforcement Act (FIRREA). ${ }^{126}$ A 'battle of the dictionaries' ensued, both before the district court and court of appeals, to determine what 'enter into' means in the abstract. ${ }^{127}$ But the debate over semantics should not obscure the two most interesting aspects of the case.

First, district judge Huvelle concluded that NextBank was a party to the Master Indenture (despite it not having signed under the heading 'parties' as it did in the other three documents, but under the heading 'acknowledged and accepted') by constructing the four separate transaction documents as a single, joint agreement. ${ }^{128}$ This shows that, even if patrimonies and legal personalities are separate, that separation can be blurred

giving noteholders a right to bid for the collateral when this was sold, to profit from later increases in value. The court held that it was not necessary (Bank of NY Trust Co v Official Unsecured Creditors Comm (Re Pac Lumber Co), 584 F3d 229 (5th Cir 2009) at 246-50). This view, which was common to both the courts of the Fifth Circuit (as those of Re Pacific Lumber) and the Third Circuit (see Re Philadelphia Newspapers, LLC, 599 F3d 298 (3rd Cir 2010) was later refuted by the US Supreme Court in Radlax Gateway Hotel LLC v Amalgamated Bank, SCt No 11-166 (29 May 2012).

123 Bank of New York v FDIC, 453 FSupp2d 82 (DDC 2006), affd 508 F3d 1 (DC Cir 2007).

124 'Article V, $\S 5.01$ of the Master Indenture provided that, upon the appointment of a conservator, receiver, or liquidator of NextBank, "a [r] edemption [e]vent with respect to all [s]eries of [n] otes [would immediately] occur without any notice or other action on the part of the Indenture Trustee or the Noteholders' Bank of New York v FDIC, 453 FSupp2d 82 (DDC 2006 ) at 87.

125 Later, the transaction was wound up. The FDIC only refused to honour the ipso facto clause, but honoured another clause that provided for acceleration when certain financial performance thresholds were not met. Note classes A and B were paid in full, and $\mathrm{C}$ in half.

126 'The FDIC further explained that, under Section 1821(e)(12)(A), "'the FDIC as receiver [has] the authority to enforce contracts entered into by [a] depository institution in receivership notwithstanding any contract clause providing for termination, acceleration or default solely by reason of insolvency or the appointment of the receiver.' Bank of New York $v$ FDIC, 453 FSupp2d 82 (DDC 2006) at 90.

127 The definition of the Black's Law Dictionary (which equated 'enter into' with 'become a party to', and favoured BNY's restrictive approach) was confronted with those of other texts (which supported the FDIC's contention that the term was more ambiguous, and should thus be constructed pursuant to a systematic interpretation of the text). See Bank of New York $v$ FDIC, 453 FSupp2d 82 (DDC 2006) at 93, and, on appeal, 508 F3d 1 (DC Cir 2007) at 4-5.

128 BNY argued that, to determine the FDIC's power under FIRREA to enforce contracts 'entered into' by the depository institution notwithstanding ipso facto clauses, the concept of 'enter into' had to be interpreted pursuant to state's contract law; whereas the court upheld the FDIC's view that 'enter into' was an autonomous concept in a federal statute. This saved the need for a decision over NextBank's contract status. However, the court went further and held that the conclusion would have been the same under contract law. However, the court never clarified whether this meant that there was one single contract, four separate contracts whose interrelationship made NextBank a party to all, or a contract whose relationship with the other three made NextBank a third-party beneficiary. 
through contract and statutory interpretation, on the basis of the transaction's internal functioning.

Second, the FDIC did not use its more drastic powers to repudiate the completed transfers of financial assets (equivalent to avoidance and re-characterization analysed at 'Threats to the asset transfer: avoidance and re-characterization' section), as federal statutory rules protected securitization, and limited the FDIC's ability to repudiate the transfer.

Thus, rather than try and undo the transfer, the FDIC in NextBank used its more modest powers to 'enforce transactions', and kept the transaction going, despite the acceleration clause, ${ }^{129}$ to avoid disrupting the bank's securitization activity. Since concerns about bankruptcy-remoteness have mostly focused on avoidance/re-characterization, the power to 'enforce' a transaction is purportedly less harmful, and thus subject to less restrictions. This tour-de-force by the FDIC put the trustee in the odd and uncomfortable position of having to make the broader and policy-based argument that the rules needed a substantive and finalistic interpretation to preserve securitization, because that was their intended purpose. As usual, the policy argument (even if this time was framed in support of securitization) was rejected by the court. ${ }^{130}$

The saga did not end here; eventually the FDIC could not gain hold of the assets on the basis of other fact-specific arguments, ${ }^{131}$ but this case is an example of how transactions relying heavily on form, albeit 'shielded' from the drastic avoidance, re-characterization or consolidation remedies, are not immune to other threats when the SPV/SPE, in substance, is dependent of its sponsor. Even without setting precedents the vehicle's

129 The power used was contained in s 1821 (e) (12) (A), unlike the power to repudiate completed transfers, which was contained in s 1821 (e) (1), required the bank to have been a 'party', and triggered the limitation (securitization-protection) Rule contained in 12 [CFR §] 360.6. For further examples of the relationship between ipso facto clauses and bankruptcy principles, see the Perpetual Trustee case infra "Synthetic transactions and priority flips".

130 BNY argued, first, that the regulatory limitation, restricted to the FDIC's use of its power to repudiate transactions, should be interpreted broadly, as 'a statement that the agency would not interfere with any of the "[investor] risk-reduction elements of a securitization"'. The court dismissed the argument because the limitation of the FIDC's powers was narrow and restricted. See Bank of New York v FDIC, 453 FSupp2d 82 (DDC 2006) at 98, and, on appeal, 508 F3d 1 (DC Cir 2007) at 5-6. Then, the court dismissed BNY's argument that the FDIC's move threatened the 'legal isolation' of the assets necessary to receive accounting and regulatory beneficial treatment as a 'transfer', holding that 'sale' or 'transfer' accounting treatment should be granted as long as the FDIC could not 'recover or reclaim' the transferred assets in the event of receivership; and added that rating agencies did not downgrade the transaction as a result of the FDIC's exercise of its powers. ibid 97-98. Should the court have employed those arguments? What would have happened if the accounting treatment had changed as a result of upholding the FDIC's interpretation, or if rating agencies downgraded the securities? Is the court's role to interpret the FDIC's powers or to justify as 'securitization-friendly' a decision that clearly was not?

131 After the Bank of New York v FDIC, 453 FSupp2d 82 (DDC 2006) (NextBank I), examined above, in FDIC $v$ Bank of New York, 479 FSupp2d 1 (DDC 2007) (NextBank II) BNY argued that, even if FDIC used FIRREA powers properly, the ipso facto clause was still enforceable against the trustee, which had to make payments to noteholders, who threatened litigation otherwise, and that such claims should be resolved by an interpleader action in New York (an attempt to seek a more accommodating venue for noteholders' interest). Judge Huvelle held that the ipso facto clause was contrary to FIRREA, and thus unenforceable against 'any' party; and that BNY was trying to re-litigate the issue, and issued an injunction. Both NextBank I and II were confirmed in Bank of New York v FDIC, 508 F3d 1 (DC Cir 2007) by the Circuit Court. But the courts also held that matters concerning the maturity of the notes had not been decided, and could be the subject of litigation. Thus, noteholders forgot the ipso facto clause, and instructed $\mathrm{BNY}$, as trustee, to seize the collateral assets pursuant to contract clauses that had rendered their notes due and payable. Arguing that it faced conflicting claims (and maybe coordinated with the noteholders) BNY sought an interpleader dispute before New York courts, which this time encountered no injunction, where the noteholders' final right to the assets prevailed in the three decisions of Bank of New York v First Millennium, 2007 WL 1404433 (SDNY); Bank of New York v First Millennium 2008 WL 866425 (SDNY), on procedural matters; and (the most important) Bank of New York v First Millennium 598 FSupp2d 550 (SDNY 2009); all affirmed on appeal in Bank of New York v First Millennium, 607 F3d 905 (2010). 
shield will be more an aspiration than a reality if servicing and cash-management are undertaken by the sponsor/originator: if it becomes insolvent, it will be hard to both compel the sponsor/originator (or its insolvency trustee/administrator) to work for the interest of the bankruptcy-remote creditors, rather than its own creditors, or find a suitable replacement in a manner timely enough to avoid disruption. ${ }^{132}$

\section{Threats in more 'advanced' transactions: securitization of future assets, whole businesses and synthetic securitizations}

The arguments examined above are valid for 'cash' securitizations. More advanced types of transactions, while supposedly not altering the broader theoretical conclusions, can change both the outcome and the nature of the issues involved. This is the case with securitization of future assets or whole businesses; and synthetic structures.

\section{Securitization of future assets and whole business securitization}

The tension between the protection of secured and unsecured creditors matters in the field of securitization of future assets and whole business securitizations. In both cases, the effective asset partitioning and vehicle insulation must rely on the ability of securitization creditors to force the sponsor/originator to 'work for them', and service payments and collect receivables that will not go to the estate of the sponsor/originator. This can only be done by giving some control to bankruptcy-remote creditors over the originator/sponsor activities in bankruptcy.

Despite the main difficulty being the practical implementation of such control, most legal orders have focused the debate on more abstract issues, such as whether future assets can be assigned, and whether such assignment can have proprietary over the assets. This conceptual difficulty does not pose a problem in the UK or the USA, where assignments in equity of future property have long been admitted by case law; ${ }^{133}$ or expressly contemplated under statutory law. ${ }^{134}$ More problematic is the issue under the laws of civil law countries. In France, for example, assignment of future assets (typically, receivables) is only possible if the arrangement that will give existence to the right (germe d'existence) already exists (eg if the contract that will generate the right to receive the money has been concluded). ${ }^{135}$ Other countries, such as Italy or Spain, have introduced specific provisions that expressly accept the validity of agreements for the assignment of future rights in the context of financial transactions, even if the contracts that will give rise to such assets have not yet been concluded. ${ }^{136}$

As to the proprietary effect, civil law courts often insist on equating the notification to the debtor with the transfer of possession, and thus the moment when the assignment has

132 This aspect is examined with others in the section 'Resilience of securitization structures to the demise of transaction parties' in Muñoz (n 1) 77-85.

133 Holroyd $v$ Marshall [1862] 10 HL Cas 191; Tailby v Official Receiver (1888) LR 13 App Cas 523.

134 \$9-204 Uniform Commercial Code.

135 Stefano Troiano, La Cessione dei Crediti Futuri (CEDAM 1999) 236.

136 Art 3 of Act 52/1991 (Italy); Additional Provision No 3 of Act 1/1999 (Spain). 
effects upon third parties. ${ }^{137}$ In countries (eg Spain) where specific statutory rules give proprietary effects to certain financial assignments, such effects cannot take place outside the special statutory provisions. ${ }^{138}$

Validity and proprietary effects notwithstanding, neither the doctrines nor the statutory provisions solve the real practical problem of assignments of future property: future receivables require active counter-performance from the obligor, which is the originator/sponsor in this case. If the originator/sponsor is insolvent, its trustee/ administrator will have little incentive to continue the performance of contracts that generate revenues for securitization creditors, and will instead focus on the creditors of the estate: ${ }^{139}$ absent specific bankruptcy provisions that compel the trustee/administrator to continue generating revenue, bankruptcy-remote creditors' rights arising from future assets may be confined to receivables that arise without the debtor's intervention. ${ }^{140}$

The problem is more acute in cases of 'whole business securitizations', where there is no separation between the assets of originator and those of the vehicle. In view of the fact that the debtor remains in control of the assets, and is free to manage, administer and sell them, it is more difficult to fulfil the conditions for a 'true sale'; and investors' protection may have to be in the form of a security interest (as they do in UK transactions ${ }^{141}$ ); which would be a floating security. ${ }^{142}$

The structure raises difficult issues in common law countries. English law used to be particularly protective towards creditors' interests, by giving the holder of a crystallized floating charge the right to appoint an administrative receiver, who, in practice, would all but take over the business, normally to sell it and settle the debts. ${ }^{143}$

Floating charges, however, began to be seen as a threat to restructuring and rescue prospects. Statutory reform excluded the holder's right to appoint a receiver, and replaced it with the right to appoint an out-of-court administrator. ${ }^{144}$ Even though the law included an exception to this rule that could cover securitization transactions (the exception for 'capital market arrangements' ${ }^{145}$ ), it must be interpreted restrictively. This creates an incentive to use the fixed charge instead; but courts have, in the past,

137 Decisions of the Spanish Supreme Court of 27 June 2003 (RJ 2003/4313) or 18 May 1993 (RJ 1993/3565). Unless the legal relationship giving rise to the receivables predated the insolvency. See Decisions of the Spanish Supreme Court of 11 February 2003 (RJ 2003/938), or 6 November 2006 (RJ 2006/9246). In France, the Commercial Chamber, which initially did not recognize property effects to the assignment of future receivables in case of bankruptcy gradually altered its position to accommodate with the view of the Civil Chamber, which gave them property effect in bankruptcy if the relationship was pre-existent. Compare decisions by the Chambre commerciale 26 April 2000, Com Bull Civ 2000, IV, 84 and by the Chambre civile 20 March 2001, no pourvoi: 9914982, Bulletin 2001 I no 76 p 48. In Italy case law admits the validity of the assignment, but it has no property effects. See Cass 14 novembre 1996, n 9997; Cass 17 marzo 1995, n 3099, in Foro it, Rep 1995.

138 See 'Threats to the asset transfer: avoidance and re-characterization' section. Additional Provision No 3 of Act 1/1999; art 2 Royal Decree 926/1998.

139 Muñoz (n 69) 230-31.

140 Peer International Corp v Termidor Music Publishers Ltd [2002] EWHC 2675; [2003] EMLR 19, Ch D.

141 Supposedly a different approach, which achieves true sale, is undertaken in the USA, or Japan. Yusuke Murakami, 'Innovative Securitization after the Crisis? Whole Business Securitization in the U.S. and Japan' (2012) Harv L School 5-11.

142 See Roy Goode, Legal Problems of Credit and Security (Thomson 2009) 121-72.

143 See s 29 (2) Insolvency Act 1986.

144 Insolvency Act 1986 s 72A. See John Armour, Audrey Hsu and Adrian Walters, 'Corporate Insolvency in the United Kingdom: The Impact of the Enterprise Act 2002’ (2008) 5 Europ Company \& Fin L Rev 160.

145 Insolvency Act 1986 s 72B-H, Sc 2A. 
re-characterized a purportedly fixed charge as a floating charge in Re Spectrum Plus Ltd ${ }^{146}$ (predated by Agnew $v$ Commissioners of Inland Revenue ${ }^{147}$ ) if the parties' (especially the debtor's) actual rights and powers over the assets justify the 'floating' nature. ${ }^{148}$

In civil law countries the picture is even more difficult. Security over movables and rights has resulted from an expansion of the right of 'pledge', which, unlike the 'charge' relies on the transfer of possession to the creditor, a feat difficult to accomplish in a whole business securitization. The 'spiritualization' of possession has led to interesting constructions, such as the pegno rotativo under Italian law; ${ }^{149}$ which is nonetheless absent from other countries such as France or Spain (because it arguably stretches the pledge's limits too far $^{150}$ ).

Achieving the same outcome by means of other legal figures is problematic: the institution of 'legal subrogation' (subrogación real, subrogation reéle) from Roman and medieval law, implies that proprietary/security rights can be extended to the assets that replace those originally subjected to the property/security right, but it has a remedial (ie not contractual) character, ${ }^{151}$ which means that it is shaped by the court's balancing of equities, not the parties' contractual stipulations. And while there are specific statutory rules that regulate non-possessory security interests, those have restricted application, and do not seem to support a transfer as broad and open-ended as that required under a whole business securitization. ${ }^{152}$

Only if the scope of those norms on non-possessory security interests were expanded, could the system be transformed from one based on possession to one based on registration or simple consensus plus identification of the property. Still, the practical problem of administering the bankrupt estate for the benefit of bankruptcy-remote creditors would persist in the absence of a specific regime, such as receivership, and such change seems unlikely in the near future.

In fact, in Spain the issue of a potential sobregarantía (overcollateralization) understood as an abuse from creditor to debtor which can justify the setting aside of the assignment, is often discussed in relation with assignment of future assets. ${ }^{153}$

146 Re Spectrum Plus Ltd [2005] UKHL 41.

147 Agnew v Commissioners of Inland Revenue [2001] 2 AC 710, 722, para 22 per Millett.

148 Re Spectrum Plus Ltd [2005] UKHL 41, paras 53ff.

149 Enrico Gabrielli, Il pegno anomalo (CEDAM 1990); Sulle garanzie rotative (ESI 1998); 'Il pegno' in Rodolfo Sacco (dir) Trattato di diritto civile (UTET 2005).

150 See Muñoz (n 69) 216-27, and authorities cited.

151 The institution was used in cases where an asset was destroyed and replaced by another, so there was an 'objective' connection, rather than the simple identification in the security's documents. See Muñoz (n 69) 218-21, and authorities cited. If the argument used is that of 'affected patrimonies', the issue is the admissibility of the trust in civil law countries. Spain has passed no rules on the issue (which makes it more difficult), Italy or France have, but the problem remains what happens if the transfer falls outside the scope of the specific rules. ibid 221-22.

152 Those provisions are the exception, not the rule, for security interests. Thus, if the security right over movables envisaged by the parties falls outside the specific statutory rules, one must resort to the general principles of the right of pledge; which require the transfer of possession. In the Spanish Supreme Court Decision of 21 March 2006 (RJ 2006/1589), the Court held that the noncompliance with the registration in the special Register for Hipoteca Mobiliaria y Prenda sin Desplazamiento is a 'constitutive' requisite (ie necessary for the right to arise) rather than a 'declarative' requisite (which gives publicity to an already existing right). Absent registration the right is not automatically transformed into a right of pledge either, if the requirement possession is not complied with. The Court held that the purported right was invalid. See Muñoz (n 69) 224-27.

153 Muñoz (n 69) 215, fn 221. 
Its contours are, for now, mostly theoretical (because recourse to the assignment of future assets has been too restricted in Spain to give rise to claims of abuse) but the issue would arise if, say, the law were to support whole business securitizations with protections such as receivership. Receivership, however, is in retreat even in the country that was its principal proponent (the UK). This reminds us that, no matter the specificity of the mechanism, the policy argument is never far away from securitization.

\section{Synthetic transactions and priority flips}

The concept of a vehicle's shielding can have different sides, and the protection of the interests of securitization investors can rely on considerations other than the property over the assets whose risk is transferred, as the Perpetual Trustee litigation showed, in the context of a synthetic transaction in the midst of the Lehman Brothers bankruptcy.

In the Perpetual case, the SPV/SPE was set up in a low tax jurisdiction, issued notes and used the cash to purchase government bonds and other safe assets. Those assets acted as collateral to insure against the risk of default of some Reference Obligations held by a Lehman entity (Lehman Brothers Special Financing, or LBSF), a risk that was transferred by means of a CDS: ${ }^{154}$ in exchange for the sums yielded by collateral assets Lehman would pay the sums owed to noteholders (the excess between both sums being considered a risk or insurance 'premium'; in case of an Event of Default LBSF would take possession of collateral assets.

It is important to stress that the problem differs from the one in a traditional 'cash' securitization. In a cash securitization what matters is the property right over the assets transferred to the vehicle. ${ }^{155}$ In a synthetic transaction there are, first, the assets whose risk is transferred (Reference Obligations) and, then, the assets used as collateral. What mattered in the case was the rights over the collateral, which was used both to protect the swap counterparty (LBSF) from the default of the assets and, at the same time, to protect noteholders from the default of LBSF. This double protection with the same assets was instrumented through a 'priority flip': LBSF's security right over the collateral had priority, unless LBSF defaulted, in which case the priority would 'flip over' to the noteholders. ${ }^{156}$ Since its effect was to snatch the assets from the reach of an insolvent entity, LBSF's bankruptcy trustee failed to appreciate the ingenuity of the clause.

To complicate the matter further, the 'flip' could be triggered by the insolvency of LBSF itself, but also of the group's parent, Lehman Brothers Holdings Inc (LBHI). Upon the claims of Lehman Brothers' bankruptcy administration, the validity of the clause was discussed before the UK and US courts. In the UK, the courts decided the case on the basis of the general 'anti-deprivation' doctrine, which states that: 'there cannot be a valid

154 See Perpetual Trustee Co Ltd y BNY Corporate Trustee Services Ltd [2009] EWCA Civ 1160; [2010] Bus LR 632; [2010] BCC 59; [2010] BPIR 174 for more details.

155 That is, the assets whose risk is transferred are the same assets whose property is transferred.

156 This gives this type of clauses the name by which they have come to be known. See Sarah Worthington, 'Insolvency Deprivation, Public Policy and Priority Flip Clauses' (2010) 7(1) Int Corp Rescue 28-29. 
contract that a man's property shall remain his until bankruptcy, and on the happening of that event go over to someone else, and be taken from his creditors' ${ }^{157}$

That doctrine has inspired specific statutory provisions that regulate claw-backs or adjustment. $^{158}$ Thus, the doctrine itself has been losing ground, and enjoys limited application, which raised doubts about its actual meaning. The Court of Appeal, upholding the decision of the High Court, held that the priority-flip was valid pursuant to the anti-deprivation principle because: (1) Collateral assets had been acquired with the noteholders' money; (2) the 'effect of the "flip" provisions was thus not to divest LBSF of monies, property, or debts; but, rather, merely to change the order of priorities in which the rights were to be exercised in relation to the proceeds of sale of the collateral in the event of a default'; ${ }^{159}$ (3) as the security right granted to LBSF included, from its inception, with the 'priority flip' the right had always been a contingent one; (4) the priority flip clause was activated not by the insolvency of LBSF (the entity that would have been 'deprived') but the insolvency of its parent, LBHI; which occurred before LBSF filed for insolvency.

Not all arguments are equally convincing. The first argument is hardly relevant or supported by precedent; ${ }^{160}$ and the second interprets the concept of 'divestment of property' in a formalistic way which could render the doctrine ineffective (in purity, pursuant to this interpretation a security over previously unencumbered debtor's assets would not be a divestment of property either). ${ }^{161}$

The third of the Court's arguments is more subtle; and raises the wider issue of the limits of party autonomy in shaping property and security rights. The Court held that the senior security right held by the swap counterparty was, since its inception, a contingent one. The question is whether the parties could create such a right, which changes priority upon insolvency. Professor Sarah Worthington has argued that they could not, pursuant to a distinction, which she drew from previous case law, between proprietary interests, that can 'only' and 'necessarily' be defined in a time limited way, such as leases, and 'all other' interests, including charges, as is the case. ${ }^{162}$ Under the first type of right the parties can shape the limitation; under the second, introducing a time limit does not shape a defining feature of the right, but effects a 'deprivation'. ${ }^{163}$

Resorting to the 'intrinsic' or 'necessary' characteristics of a property right comes naturally to a civil law lawyer, since the numerus clausus doctrine implies that no

157 Re Harrison (1880) 14 Ch D 19, 26 by Cotton LJ. See also Money Markets International Stockbrokers Ltd v London Stock Exchange Ltd [2002] 1 WLR 1150 at 87.

158 See current ss 238-246 of the Insolvency Act 1986.

159 Perpetual Trustee Co Ltd v BNY Corporate Trustee Services Ltd [2009] EWCA Civ 1160; [2010] Bus LR 632; [2010] BCC 59; [2010] BPIR 174 at 62.

160 See Worthington (n 156) 31, with reference to Re Goldcorp Exchange Ltd (in rec) [1995] 1 AC 74 (PC); Re London Wine Company (Shippers) Ltd [1986] PCC 121. Furthermore, it would draw an artificial distinction between funded and unfunded synthetic securitizations; and would raise doubts in cases where collateral assets happen to have been acquired by the swap counterparty before being transferred to the vehicle.

161 Not very consistent with the anti-deprivation nature of back-up doctrine.

162 Worthington (n 156) 37, with reference to Money Markets International Stockbrokers Ltd v London Stock Exchange Ltd [2002]

1 WLR 1150 at 37 and 118; Ex parte Jay, re Harrison (1879) 14 Ch D 19 at 26, and the authorities cited in Perpetual Trustee.

163 Worthington (n 156) 37-38. 
property/security rights can be created beyond those contemplated by the law; ${ }^{164}$ but also that the intrinsic characteristics of a right cannot be altered to de-naturalize the right. ${ }^{165}$ The question is whether that logic, under which party autonomy is limited by the intrinsic characteristics of the security, applies in a common law context. ${ }^{166}$ Even if it did (and the argument by Prof. Worthington was very persuasively put) the back-up argument of the British court to uphold the clause was that it was activated 'before' the debtor's bankruptcy took place, a factor that, everyone agreed, precluded the application of the British anti-deprivation doctrine. ${ }^{167}$

The case, however, was discussed again before courts in the USA, and under American law. ${ }^{168}$ This time the basis was not a general doctrine, but the specific statutory provisions that render unenforceable the so-called ipso facto clauses, ie clauses that seek to 'terminate or modify' the contract, or 'any right or obligation' under the contract as a result of the beginning of 'a case', ie bankruptcy'. ${ }^{169}$

That such statutory provisions, unlike the British doctrine, would render the priority flip invalid if they were applied, was clear. Thus, the whole discussion turned on the interpretation of the statutory concept of the 'beginning of a case'. Judge Peck held (unlike his British counterparts) that the clause was invalid because, pursuant to the transaction documents, it was LBSF's insolvency, not LBHI's (its parent's) that triggered the clause. ${ }^{170}$ However, he also held that the result would have been the same if the clause had been triggered by LBHI's insolvency, because, in his understanding, the reference to 'a case', rather than 'the case' applied not only to the bankruptcy of the party whose contract was modified as a result of the clause, but also to other related parties. ${ }^{171}$ In the case at hand, the functioning of the Lehman entities as an 'integrated enterprise'; whose effect was that 'the financial condition of one affiliate affects the others' created the conditions to treat their bankruptcy filings as a 'singular event for purposes of interpreting this ipso facto language', and 'the first filing at the holding company level' as a valid application of the reference to 'a' case.

The judge's view reflected a method with which we are already familiar, where a solution is reached that does not uphold the parties' asset partitioning, or vehicle shielding,

164 Luis Díez-Picazo, Fundamentos del Derecho Civil Patrimonial. III. Las relaciones jurídico-reales. El Registro de la Propiedad. La posesión (Civitas, 2008) 131ff.

165 ibid 132-33.

166 Some scholars have shown that numerus clausus exists in common law countries, only it does not have a name. See Thomas W Merrill and Henry E Smith, 'Optimal Standardization in the Law of Property: The Numerus Clausus Principle' (2001) 110 Yale LJ $1-70$.

167 Worthington (n 156) 38.

168 Lehman Brothers Special Financing Inc v BNY Corporate Trustee Services Ltd (Re Lehman Brothers Holdings Inc) No: 09-01242 (JMP) US Bankr Ct SDNY January 25 (2010) per Peck J.

169 See ss 365 (e) and 541 (c) (1) (B) of the Bankruptcy Code. The wide scope of the provision, which refers to 'modification', left no room to discuss the 'divestment of property' concept, as under English law.

170 Lehman Brothers Special Financing Inc v BNY Corporate Trustee Services Ltd (Re Lehman Brothers Holdings Inc) No: 09-01242 (JMP) US Bankr Ct SDNY January 25 (2010) per Peck J at 16-17.

171 In this regard, the court referred to earlier versions of ss 365 (e) (1) and 541 (c) (1) (B), which referred, respectively, to 'the commencement of a case under this Act by or against the debtor', and 'the commencement of a case under this title concerning the debtor', references that were eventually suppressed in favour of the more generic reference to 'a case', thereby reinforcing the view that the wider language was not random, but on purpose. 
arrangements, but such solution does not set a precedent. This time judge Peck expressly stated that nothing in the decision should affect 'issues of substantive consolidation, the importance of each of the separate petition dates for purposes of allowing claims against each of the debtors or any other legal determination'; and the decision avoided more general and abstract pronouncements that would open a 'can of worms'. But it is yet another example that the (especially American) courts' unwillingness to signal a wide departure from the strict rules on separation of patrimonies is mitigated by their willingness to adopt decisions that have that effect, provided they are restricted to the specific circumstances of the case. The question left open was what should be the elements that must be taken into consideration to decide that an ipso facto clause is invalid, when the fact that it is not triggered by the insolvency of the company whose arrangement is modified, but by the insolvency of another company: is it the dependence between entities, cause-effect between their two bankruptcies or something else? The later settlement ${ }^{172}$ only plastered over a crack between the ways courts can understand a single issue.

\section{Conclusion: the devil in the details}

Academic analysis tries to explain legal phenomena in terms that are clear, comprehensive and without sharp edges. When confronting bankruptcy-remote structures there is a strong temptation to both see them as a borderline example, and to paint them in an invariably positive or negative light. Yet such an approach is wrong for two reasons. First, treating bankruptcy-remote structures as an anecdote misses their importance in policy terms: their widespread use has made them natural substitutes of security interests in large-scale transactions, and the decision of whether to respect or unravel them will be seen as a strong indication of the law's broader stance on asset partitioning in bankruptcy.

Second, a black-or-white approach will miss the importance of details in both the structures and the law (both statutory and case law) applicable to them. Overly negative views of securitization, which characterize it in light of its pathological use, can miss that securitization is not more dangerous for general creditors than a division, spin-off, or asset sale. ${ }^{173}$ Using doctrines of abuse of law (in civil law countries) or equitable powers (in the USA) requires something else than the mere ascertainment that unsecured creditors, or society as a whole, would be better-off if the transaction was undone or recharacterized, or the vehicle consolidated. In this sense, the policy debate has not given courts a useful framework to decide.

The courts seem to agree: there are no known instances where the separate personality of a bankruptcy-remote vehicle has been disregarded pursuant to veil piercing or substantive consolidation doctrines; or the asset transfer unravelled based on creditor

172 'Lehman Ends Suit With BNY Mellon, Perpetual Trustee' (The Wall Street Journal, 15 December 2010) <http://online.wsj. com/article/SB10001424052748704098304576021560555088914.html> accessed 17 June 2014.

173 Professor LoPucki also classified the parent-subsidiary relationship as a source of judgment-proofing strategies (see LoPucki $\mathrm{n}$ (21) 20-23), although this time he specifies that the judgment-proofing strategy is only present when 'the debtor isolates the most valuable assets of the business in an entity other than the one that conducts the liability producing business activity'. ibid 20 . 
fraud, or re-characterization doctrines. Furthermore, courts have stood clear of a 'policy' analysis except to support bankruptcy-remote structures, or warn about the perils of using policy arguments in the absence of clear limits.

This does not mean securitization is invariably protected, nor that the tension between the interest of bankruptcy-remote creditors, on one hand, and the interest of the debtor and unsecured creditors on the other hand, is absent from statutory provisions or court practice. A closer look shows that, while rejecting substantive consolidation, courts have been more willing to (1) accept 'procedural' consolidation of the originator/sponsor's and the entity's bankruptcy proceedings, or (2) give the originator/sponsor possession and control over securitized assets on an interim basis. Thus, the policy argument is relevant provided we switch the discussion from 'ownership' to 'control', and from 'permanent' to 'interim' situations.

As one moves to more 'advanced' transaction types, the complexity of these transactions gives the courts a respite to focus even more on the policy implications of the decision (they can always hide behind the highly fact-specific nature of the case). ${ }^{174}$ Thus, arguments of abuse, substance-over-form or finalistic interpretation are never far from the surface in securitizations of future assets, or revolving pools, or synthetic structures. The only case involving the latter was decided (in opposite senses) pursuant to the broad and residual 'antideprivation' doctrine in the UK, and pursuant to a finalistic interpretation of statutory provisions to invalidate ipso facto clauses in the USA.

The experience is still insufficient to draw definitive and general conclusions, but existing evidence suggest that securitization and bankruptcy-remote transactions, while embraced by bankruptcy law as a 'normal' mechanism of asset partitioning, have not been given an a-critical blessing. The clash between bankruptcy policies and the balance between debtor and creditors is still present in statutes and court decisions, only in ways different from those initially envisaged.

Thus, the terms of the debate need to change, in ways that are useful to solve real problems. Navigating the troubled waters of bankruptcy policy is never easy, and guidance is often overwhelming and contradictory. But courts and legislatures are doing so in a more than acceptable manner. Academics could oblige by providing theories that suit the facts, rather than interpretations of the facts that suit the theories.

174 Only in cases where a statutory reform has taken place (as the limitation of receivership in the UK) has the policy argument been explicit. The restriction of receivership not only results in a limited scope of application, but may also result in a restrictive interpretation in borderline cases. Even though an exception is introduced in the statute for 'capital market transactions' there is a grey area of which instruments are admissible under that exception; and careful analysis is required before concluding that receivership is admissible. For a practitioners' view confirming this issue, in relation to securitization, see Robin Parsons, Philip Taylor and Alex Rovira, 'Asset securitisation and the effect of insolvency on special purpose vehicles' <http://www. europeanrestructuring.com/05intro/036 041.htm>. 